ISSN 2078-6077.

Наукові зошити історичного факультету Львівського університету. 2020. Випуск 21. С. 11-40

Proceedings of History Faculty of Lviv University. 2020. Issue 21. P. 11-40

УДК: 94 (477)’ 1932/ 1933”: 930.253(477)-058.64

\title{
ПЕРВИННІ ДОКУМЕНТИ УКРАЇНСЬКИХ АРХІВІВ ЯК ГОЛОВНЕ ДЖЕРЕЛО ДЛЯ ВСТАНОВЛЕННЯ КІЛЬКОСТІ ВТРАТ ПІД ЧАС ГОЛОДОМОРУ-ГЕНОЦИДУ 1932-1933 років
}

\author{
Володимир СЕРГІЙЧУК \\ Київський національний університет імені Тараса Шевченка \\ кафедра історії світового українства \\ вул. Володимирська, 60 Київ, 01033, Україна \\ e-mail:serhiychuk@ukr.net
}

\begin{abstract}
У статті зроблено оцінку напрацювань української та зарубіжної історичної та демографічної науки щодо підрахунку жертв Голодомору-геноциду 1932-1933 років в Україні й запропонувано нові підходи в досягненні реального результату. Методика дослідження спирається на загальні наукові методи аналізу, порівняння та узагальнення. Також застосовано порівняльно-історичний, структурний і системно-функціональні методи. Уперше здійснено підрахунок жертв Голодоморугеноциду 1932-1933 років на основі виявлених офіційних даних радянської статистики про кількість населення УСРР станом на 1 січня 1932 року і розрахованої його кількости на 1 січня 1934 року. Крім того, як допоміжний метод було застосовано порівняльний аналіз кількости народжених в УСРР в 1924-1932 роках з наповненістю перших класів у 1932-1940 роках дітьми 8-річного віку (саме вони тоді вперше приходили до школи) з врахуванням коефіцієнта природних втрат у цих вікових групах. Автор доходить висновку, що з огляду на відсутність архівних документів про конкретні втрати від Голодомору-геноциду в 1932-1933 роках в Україні лише ретельний аналіз наявних первинних документів дає можливість встановити максимально наближену до реальної кількість жертв цієї трагедії нашого народу. Завдяки саме цьому вдалося встановити офіційну цифру кількости населення УСРР станом на 1 січня 1932 року і розрахувати ії на 1 січня 1934 року, що дає підстави стверджувати про мінімальні втрати під час Голодомору-геноциду в 7 мільйонів осіб. Вказана цифра підтверджується і завдяки аналізові наповнености перших класів дітьми 8річного віку, які в той час саме в такому віці вперше приходили до школи, в багатьох районах Київщини, Черкащини, Вінниччини, Полтавщини. Наприклад, у Таращанському районі Київської області, в 1928 році народилася 2.659 дитини, а 1936 року з них за парти сіли в перших класах всього 1073. Подібна картина і в селах лівобережного Переяславського району - 33487 немовлят 1931 року до 1939 року дожили лише 1591. Якщо допустити природні втрати за нормальної ситуації навіть до 20 відсотків, то в обох випадках дитяча смертність внаслідок Голодомору мала катастрофічні наслідки: приблизно 40 відсотків від народжених у відповідні роки. Такі ж трагічні результати одержуємо, аналізуючи первинні документи Оратівського, Плисківського та Погребищенського районів Вінниччини, в абсолютній більшості шкіл Полтавщини. Враховуючи те, що в 1924-1932 роках в УСРР народилося близько 10 мільйонів дітей, їхні втрати під час Голодомору-геноциду становили мінімум 3 мільйони, а з числа школярів, народжених до 1924 року, померло тоді ще приблизно 500 тисяч. Тобто, дитяча смертність шкільного віку сягнула в 1932-1933 роках мінімум 3,5 мільйона осіб, а загальна, як і свідчили тоді німецькі дипломати, від 7 до 10 мільйонів. Остаточний результат можна встановити після підрахунку смертей тих, хто пішов з українських сіл у пошуках хліба і помер у Росії чи Білорусі, або по дорозі до цих регіонів - у нас досі не досліджено жодного з 837 місць масового поховання біля залізничних станцій чи річкових пристаней, ніхто не порахував тих, хто потонув у Збручі чи Дністрі, тікаючи від голоду в Польщу чи Румунію, або кого там розстріляли радянські прикордонники. Також досі не пораховано, скільки завезено в 1932-1936 роках робочої сили з інших республік, яка під час Всесоюзного перепису 1937 року вже зафіксована мешканцями УСРР.
\end{abstract}

Ключові слова: Голодомор-геноцид 1932-1933 років, підрахунок втрат на базі первинних документів, наповненість перших класів початкової школи в 1932-1940 роках.

(C) Сергійчук В., 2020 
ISSN 2078-6077. Наукові зошити історичного факультету Львівського університету. 2020. Випуск 21. Proceedings of History Faculty of Lviv University. 2020. Issue 21.

Останніми роками в українській історичній науці загострилося питання щодо підрахунку втрат від Голодомору-геноциду 1932-1933 років. Активізували цей процес керівники українських наукових інституцій Північної Америки, які восени 2015 р. підписали привезений з Києва проєкт листа до голови Оргкомітету 3 відкриття пам'ятника жертвам Голодомору-геноциду 1932-1933 років у Вашингтоні Михайла Савківа-молодшого з проханням не називати цифри втрат від 7 до 10 мільйонів, як це вже було звичним у діяспорі, а говорити про 3,5 мільйона, оскільки про це, мовляв, пишуть Тімоті Снайдер, Андре Граціозі та Станіслав Кульчицький.

А паралельно зі згаданим листом 3'являється і стаття "Втрати міського й сільського населення України внаслідок Голодомору в 1932-1934 рр.”, автори якої (демографи й історики) пишуть: “упродовж 1932-1933 рр. близько 8,7 млн смертей у СРСР було спричинено голодом. Майже 98 \% цих втрат припадає на три радянських республіки: Україну (3,9 млн), Росію (3,3 млн) та Казахстан (1,3 млн). Якщо розраховувати відносні втрати, тобто в розрахунку на 1000 населення, Україна посідає друге місце після Казахстану. Втрати від голоду становлять $22 \%$ від загальної чисельности населення Казахстану, 17 \% - в Україні, 3 \% - у Росії та менше $2 \%$ - в інших республіках колишнього СРСР"”*. Через два роки в "УГЖ” друкується ще одна стаття на тему втрат від Голодомору ${ }^{2}$.

Насамперед, у цих публікаціях звертає на себе увагу розширення часових рамок Голодомору $з$ долученням 1934 р., що суперечить уже встановленій i закріпленій в історичній пам'яті цієї трагедії саме в 1932-1933 роках. Також ця новація не підкріплюється й відповідними архівними матеріялами. Наприклад, за даними Таращанського району Київської області, де найкраще збереглися документи ЗАГСу за 1924-1934 роки, бачимо різке зменшення смертности в 1934 в порівнянні до попередніх ${ }^{3}$ :

\begin{tabular}{|l|r|r|r|r|r|r|r|r|r|r|r|}
\hline $\begin{array}{l}\text { Село / } \\
\text { Рік }\end{array}$ & 1924 & 1925 & 1926 & 1927 & $\mathbf{1 9 2 8}$ & $\mathbf{1 9 2 9}$ & 1930 & 1931 & $\mathbf{1 9 3 2}$ & $\mathbf{1 9 3 3}$ & 1934 \\
\hline Таращ; & 188 & 158 & 168 & 143 & $\mathbf{1 4 5}$ & $\mathbf{1 5 9}$ & 137 & 119 & $\mathbf{2 2 1}$ & $\mathbf{5 0 3}$ & 120 \\
\hline Бовкун & 20 & 27 & 28 & 32 & $\mathbf{1 8}$ & $\mathbf{1 8}$ & 8 & 21 & $\mathbf{1 9}$ & $\mathbf{1 3 1}$ & 7 \\
\hline $\begin{array}{l}\text { Вел Бер } \\
\text { зянка }\end{array}$ & 47 & 63 & 84 & 96 & $\mathbf{6 3}$ & $\mathbf{6 8}$ & 51 & 51 & $\mathbf{8 1}$ & $\mathbf{3 9 6}$ & 13 \\
\hline $\begin{array}{l}\text { Вел Вов } \\
\text { нянка }\end{array}$ & 47 & 75 & 88 & 41 & $\mathbf{6 0}$ & $\mathbf{5 0}$ & 59 & 34 & $\mathbf{9 7}$ & $\mathbf{5 7 5}$ & 23 \\
\hline $\begin{array}{l}\text { Весели } \\
\text { Кут }\end{array}$ & 28 & 32 & 48 & 27 & $\mathbf{2 8}$ & $\mathbf{1 9}$ & 24 & 29 & $\mathbf{5 9}$ & $\mathbf{2 7 8}$ & 32 \\
\hline
\end{tabular}

${ }^{1}$ Н. Левчук, Т. Боряк, “Втрати міського й сільського населення України внаслідок Голодомору в 1932-1934 рр.”, Украйнський історичний журнал, № 4, 2005): 87.

* У 2018 році наші демографи для Радіо Свобода дають інші цифри: Казахстан - 22,4%, Україна “ $\mathbf{1 3 , 3 \%}$, а Росія - 3,2 \%.

${ }^{2}$ О. Воловина, С. Плохій, "Регіональні відмінності втрат від голоду 1932 - 1934 рр. в Україні”, Украӥнський історичний журнал, № 2 (2017): 76-116.

${ }^{3}$ Державний архів Харківської області (далі “ДАХО) ф. Р-6531, оп. 101, спр. 4, арк. 24-26. 
ISSN 2078-6077. Наукові зошити історичного факультету Львівського університету. 2020. Випуск 21. Proceedings of History Faculty of Lviv University. 2020. Issue 21.

\begin{tabular}{|l|r|r|r|r|r|r|r|r|r|r|r|}
\hline $\begin{array}{l}\text { Володи- } \\
\text { мирівка }\end{array}$ & 40 & 37 & 50 & 26 & $\mathbf{2 6}$ & $\mathbf{2 0}$ & 24 & 20 & $\mathbf{2 9}$ & $\mathbf{1 4 5}$ & 12 \\
\hline Дубівка & 8 & 23 & 32 & 30 & $\mathbf{1 2}$ & $\mathbf{2 1}$ & 24 & 19 & $\mathbf{4 5}$ & $\mathbf{1 1 7}$ & 6 \\
\hline Кирдани & 34 & 30 & 21 & 30 & $\mathbf{1 9}$ & - & 20 & 14 & $\mathbf{3 0}$ & $\mathbf{1 6 5}$ & 11 \\
\hline Кислі вка & 27 & 31 & 41 & - & $\mathbf{3 6}$ & $\mathbf{1 9}$ & 21 & 23 & $\mathbf{2 5}$ & $\mathbf{1 2 9}$ & 20 \\
\hline Ківшоват & 111 & 90 & 124 & 103 & $\mathbf{7 8}$ & $\mathbf{7 5}$ & 72 & 86 & $\mathbf{1 0 4}$ & $\mathbf{2 8 7}$ & 43 \\
\hline Косяківке & 33 & 39 & 47 & 27 & $\mathbf{3 6}$ & $\mathbf{3 1}$ & 31 & 26 & $\mathbf{3 9}$ & $\mathbf{4 3}$ & 7 \\
\hline Крива & 11 & 28 & 32 & 17 & - & - & - & 24 & 7 & $\mathbf{1 0}$ & - \\
\hline $\begin{array}{l}\text { Круті } \\
\text { Горби }\end{array}$ & 37 & 24 & 52 & 41 & $\mathbf{3 1}$ & $\mathbf{2 6}$ & 16 & 24 & $\mathbf{8 5}$ & $\mathbf{1 6 7}$ & 14 \\
\hline Лісовичі & 149 & 100 & 115 & 97 & $\mathbf{1 3 1}$ & $\mathbf{9 8}$ & 95 & 99 & $\mathbf{2 1 8}$ & $\mathbf{5 2 5}$ & 48 \\
\hline Лука & 94 & 73 & 95 & 112 & $\mathbf{7 3}$ & $\mathbf{7 1}$ & 61 & 38 & $\mathbf{4 2}$ & $\mathbf{3 3 6}$ & 24 \\
\hline Лук'янівк & 42 & 32 & 58 & 40 & $\mathbf{5 1}$ & $\mathbf{2 5}$ & 38 & 40 & $\mathbf{5 7}$ & $\mathbf{1 7 1}$ & 11 \\
\hline $\begin{array}{l}\text { Мала } \\
\text { Березянке }\end{array}$ & 22 & 16 & 43 & 28 & $\mathbf{2 7}$ & $\mathbf{2 4}$ & 25 & 30 & $\mathbf{6 2}$ & $\mathbf{1 8 4}$ & - \\
\hline Петрівсь & 56 & 80 & 81 & 67 & $\mathbf{4 9}$ & $\mathbf{7 3}$ & 62 & 65 & $\mathbf{9 8}$ & $\mathbf{5 0 7}$ & 21 \\
\hline Плоске & 29 & 26 & 51 & 48 & $\mathbf{3 0}$ & $\mathbf{2 6}$ & 36 & 26 & $\mathbf{1 8}$ & $\mathbf{2 5 0}$ & 22 \\
\hline Потоки & 8 & 16 & 15 & - & $\mathbf{8}$ & $\mathbf{1 3}$ & 15 & 18 & $\mathbf{4 2}$ & $\mathbf{1 3 9}$ & 2 \\
\hline Ріжки & 59 & 55 & 73 & 49 & $\mathbf{3 5}$ & $\mathbf{6 4}$ & - & 58 & $\mathbf{9 0}$ & $\mathbf{4 7 0}$ & 17 \\
\hline Салиха & 35 & 34 & 41 & 47 & $\mathbf{4 3}$ & $\mathbf{2 4}$ & 46 & 85 & $\mathbf{5 1}$ & $\mathbf{2 8 9}$ & 8 \\
\hline $\begin{array}{l}\text { Севери- } \\
\text { нівка }\end{array}$ & 85 & 66 & 134 & 72 & $\mathbf{5 0}$ & $\mathbf{5 8}$ & 86 & 67 & $\mathbf{7 4}$ & $\mathbf{6 3 4}$ & 16 \\
\hline $\begin{array}{l}\text { Стани- } \\
\text { шівка }\end{array}$ & 19 & 22 & 44 & 29 & $\mathbf{2 3}$ & $\mathbf{2 4}$ & 15 & 27 & $\mathbf{1 9}$ & $\mathbf{2 7 2}$ & 26 \\
\hline Степок & 31 & 28 & 27 & 22 & $\mathbf{2 6}$ & $\mathbf{3 9}$ & 19 & 30 & $\mathbf{4 8}$ & $\mathbf{2 9 2}$ & 7 \\
\hline Улашівка & 27 & 2 & 35 & 13 & $\mathbf{2 5}$ & $\mathbf{1 2}$ & 25 & 16 & $\mathbf{2 4}$ & $\mathbf{1 1 6}$ & 15 \\
\hline Чапаївка & 64 & 85 & 120 & 74 & $\mathbf{7 5}$ & $\mathbf{7 0}$ & 60 & 41 & $\mathbf{6 7}$ & $\mathbf{8 8 3}$ & 10 \\
\hline $\begin{array}{l}\text { Яервоні } \\
\text { Яри }\end{array}$ & 8 & 15 & 39 & 47 & $\mathbf{2 0}$ & $\mathbf{2 6}$ & 16 & 21 & $\mathbf{2 7}$ & $\mathbf{1 0 2}$ & 9 \\
\hline Чернин & 36 & 63 & 59 & 43 & $\mathbf{5 1}$ & $\mathbf{3 5}$ & 30 & 32 & $\mathbf{8 9}$ & $\mathbf{4 5 8}$ & 12 \\
\hline Разом & & & & 1463 & $\mathbf{1 2 5 0}$ & $\mathbf{1 1 8 8}$ & 1116 & 1183 & $\mathbf{1 8 6 7}$ & $\mathbf{8 6 3 5}$ & 556 \\
\hline
\end{tabular}

Подібні результати автор отримав і на основі аналізу документів, що збереглися в Переяславському районі Київської, Первомайському Миколаївської, Козелецькому - Чернігівської, Оратівському й Погребищенському - Вінницької, Оріхівському - Запорізької, Старокостян-тинівському Хмельницької, а також в окремих населених пунктах Харківської, Херсонської і Дніпропетровської областей.

Крім різкого зменшення смертности в 1934 р., немає прямих директив тодішньої влади про заборону виїзду українців, як і кубанців, до Росії чи Білорусі, що практикувалося в 1932-1933 роках. Також немає ухвал влади різних рівнів, щоб вилучати все продовольство за невиконання хлібозаготівель, як це спостерігалося під час Голодомору. Відтак без подібних свідчень важко стверджувати про свідомий голодний мор з боку влади у 1934 р. 
ISSN 2078-6077. Наукові зошити історичного факультету Львівського університету. 2020. Випуск 21. Proceedings of History Faculty of Lviv University. 2020. Issue 21.

Необхідно вказати і на таку обставину, яка раніше випадала 3 поля зору дослідників Голодомору. Не тільки в Таращанському, а й у більшості районів УСРР чимало жертв Голодомору 1932-1933 років реєструвалися наступного, 1934 р. Так, уцілілі документи Кирилівської сільради Красноградського району Харківської області засвідчують: тільки 1 січня 1934 р. виписується документ про смерть Мотрі Чубач, яка сталася 13 грудня 1933, 31 січня - кончину Пилипа Бойка 3 травня 1933 і Михайла Бойка (сина) 3 червня 1933, Василя Бойка (сина) 11 червня 1933, Миколи Бойка (сина) за 15 липня 1933, Петра Бойка (сина) 10 липня $1933 \mathrm{p}^{4}$.

Такі факти виявляються і в роботі Наталинської сільради цього ж району: смерть Софії Черненко 20 серпня 1933 оформлена лише 12 січня 1933, Клави Безрідної (25 липня 1933) - 30 січня 1934, Кирила Юрченка (20 вересня 1933)19 лютого 1934, Андрія Височина (15 червня 1933) - 20 лютого $1934 \mathrm{p}^{5}$.

Вісімнадцятирічний Андрій Асеєв з сусідньої Піщанки, котрий відійшов у засвіти 10 липня 1933 р., зафіксований у книзі реєстрації тільки 13 жовтня 1934 року. Він був таким двадцятим з числа зареєстрованих у 1934 р. 99 померлих 6 .

Цікава ситуація виявлена в матеріялах ЗАГСу Борівського району Харківської області: серед 55 свідоцтв про смерть за 1934 р. по Піско-Радьківській сільській раді, з яких 12 про смерть у 1933 р, вкладено і 24 документи, що були оформлені в $1933 p^{7}$.

Така ж ситуація і на Черкащині: в селі Матусів Шполянського району померлі в 1933 р. Лука Шевченко (15 травня) записаний 12 січня 1934, Харитон Шевченко (1 липня) - 12 січня 1934, Олекса Никогда (15 травня) - 12 січня, Пилип Коваль (14 червня) - 23 лютого, Федора Коваль (23 червня) - 23 лютого, Устя Коваль (12 липня) - 23 лютого, Олекса Крижній (15 травня) - 1 березня 1934, Микола Двожик (15 червня) - 2 червня 1934, Гапка Задирпушко (28 червня) - 19 червня, Іван Задирпушко, Віра Чередниченко (1 червня) - 27 серпня 1934 p $^{8}$.

У Заячківці Христинівського району цієї ж области книга записів за 1934 рік фіксує 23 - 26 травня смерті за 1933 рік - від 10 серпня (№ 135) до 25 вересня 1933 (№ 184) - 49 випадків* . А в сусідній Орадівці 27 і 28 травня 1934 записано 42 смерті за $1933 \mathrm{p}^{9}$.

${ }^{4}$ Державний архів Харківської області (далі “ДАХО) ф. Р-6531, оп. 101, спр. 4, арк. 58-61.

${ }^{5}$ Там само, арк. 113-163.

${ }^{6}$ ДАХО, ф. Р-6531, оп. 106, спр. 7, арк. 74.

7 Державний архів Черкаської області (далі “ ДАЧО), ф. Р-5899, оп. 24, спр. 185, арк. 138 140, 151-153, 155, 176, 180, 181, 192.

8 ДАЧО, ф. Р-5899, оп. 24, спр. 73, арк. 1-30.

* Див.: ДАЧО, ф. Р-5899, оп. 20, спр. 72, арк. 1-25.

9 Державний архів Запорізької області (далі - ДАЗО), ф. Р-5593, оп. 21, спр. 207, арк. 152 153. 
Нічим не відрізнялася картина і в степових районах УСРР. Так, 23 березня 1934 р. в Басанській сільраді Пологівського району Запоріжжя фіксують смерть трьох дітей з родини Ладимира Литвина - Ладимири (24 липня 1933), Катрі (30 липня 1933) і Марії (30 липня 1933). А всього подібних записів у цій сільраді за 1934 p. $-12^{10}$.

У Вознесенській сільраді Мелітопольського району 19 подібних випадків ${ }^{11}, \mathrm{y}$ Костянтинівській $-8^{12}$, у Копанівській Оріхівського - $16^{13}$, у Малотокмачанській $10^{14}$, у Преображенській $-15^{15}$.

Подібне виявлено і серед документів Агайманської сільради Нижньосірогозького району Херсонської області за 1934 р.: на 87 записів про смерть - 55 припадає з $1933 \mathrm{p}^{16}$.

А в селі Великі Погорільці Старокостянтинівського району Хмельницької області померлу в 1932 р. Оляну Бабин зафіксували в цьому статусі лише 18 травня $1934 \mathrm{p}^{17}$.

Тож усе це вимагає ретельно вивчити збережені документи про рух населення в 1932-1933 роках, аби скорегувати допущені недоречності й створити реальну картину втрат.

Непереконливо також твердять автори згаданої статті щодо різкого збільшення смертности власне міського населення УСРР в 1933 році. На наш погляд, вони не взяли до уваги того, що зросла смертність городян у вказаний час пояснюється не лише напливом голодних селян до міста, звідки багато 3 них уже не повернулися до рідних хат, а й тодішнім підпорядкуванням значної кількости сільських рад міським. Наприклад, у Київській області було дві міськради, до складу яких входило чимало населених пунктів з сільським населенням. Скажімо, на території Житомирської міської ради мешкало 112,0 тисячі осіб, але справжніх городян нараховувалося лише 77,1тисячі, інші були жителями 20 сільських рад. Київській міській раді підпорядковувалося тоді 67 сільських рад, відтак із загальної кількости населення в 769,9 тисячі, міщанами були лише 612,9 тисячі осіб ${ }^{18}$.

У тодішній Вінницькій області Бердичівській міськраді було підпорядковано 38 сільських рад, Вінницькій - 33, на Дніпропетровщині 4 міськради керували життям хліборобів: Дніпропетровська мала в підпорядкуванні 26 сільських рад, Запорізька - 62, Кам'янська - 12, Криворізька - 35. На Донбасі таких міськрад

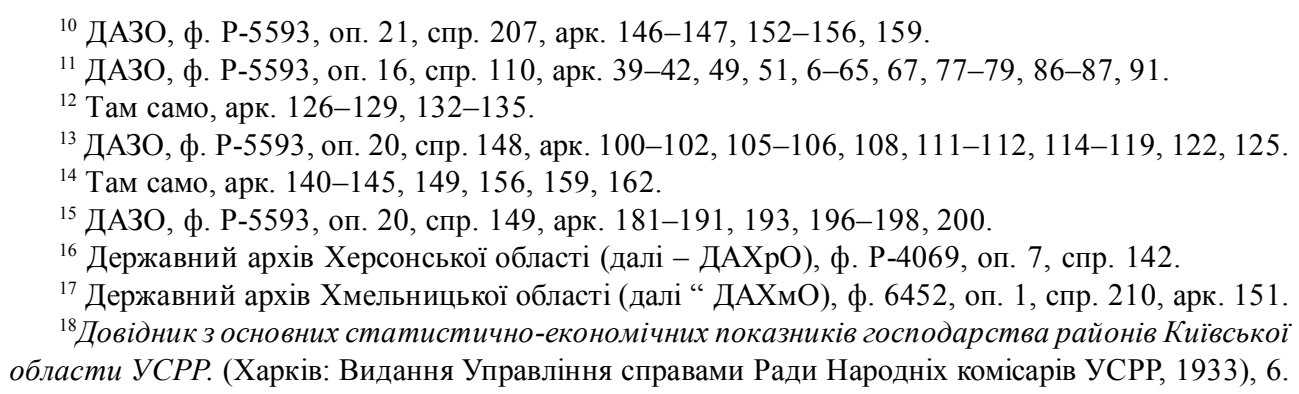


ISSN 2078-6077. Наукові зошити історичного факультету Львівського університету. 2020. Випуск 21. Proceedings of History Faculty of Lviv University. 2020. Issue 21.

було 12, Харківщині-4, Одещині - 4, Чернігівщині-1, в Молдавській Автономній Республіці - $1^{19}$.

Про це давно вже свідчили і дослідники: “Збільшення міського населення Донбасу відбувалося і за рахунок перетворення багатьох сіл в населені пункти міського типу, на основі створення в них промислових вогнищ і докорінних зрушень у професійному складі їхнього населення. Десятки сіл виявилися охопленими зростаючими містами й промисловими селищами, що впритул підходили до них і включали їх у свою межу"20.

Провідний спеціяліст Державного архіву Житомирської області Руслан Кондратюк зазначає, що понад 50 відсотків смертей, зафіксованих у Житомирі в 1932-1933 роках, не стосувалися власне тамтешніх городян. Це були "голодуючі з довколишніх сіл, які померли на міських вулицях та в лікарнях, в'язні місцевого Будинку примусових робіт (БУПРу) та Поправно-трудової установи (ПТУ). Остання група найбільш показова. Як свідчить аналіз документів, переважну їі частину складають селяни, розкуркулені та заарештовані за “саботаж”, крадіжку колосків на полях, інші прояви невдоволення політикою радянської влади. Географія таких постраждалих надзвичайно широка - від мешканців прилеглих сіл до жителів Шепетівського, Славутського, Старокостянтинівського, Могилів-Подільського та інших адміністративних районів, які входять нині до складу Хмельницької, Вінницької, Черкаської, Київської та інших областей України"21.

Більше третини смертей (акти № 624-2734), які зафіксовані в Харкові в 1933 р., наприклад, супроводжуються записами: “похоронений лікарнею” “замість адреси померлого. Записи про смерть без адреси померлого масово фіксувалися і в 1932 p. $^{22}$

А чи можна зараховувати до міських жителів тих, мертві тіла яких знімали 3 потягів і залишали на перонах залізничних станцій, після чого їх скидали неподалік у нашвидкоруч викопані ями, як правило, без належної реєстрації. А трупи багатьох, як було в Дніпропетровську взимку 1933, через замерзлу землю лежали цілими штабелями неподалік вокзалу кілька тижнів, поки їх не вивезли спеціяльним ешелоном у невідомому напрямку?

Автор цих рядків виявив ще одне джерело, яке вказує на штучне збільшення смертности власне міського населення УСРР під час Голодомору 1932 1933 років. У книгах реєстрацій актів громадянського стану про смерть за 19321933 роки в Сталінському районі Запоріжжя, наприклад, зустрічаємо велику

\footnotetext{
19 Довідники з основних статистично-економічних показників господарства районів Вінницької, Дніпропетровської, Донеиької, Харківської, Одеської Чернігівської областей і АМСРР. (Харків: Видання Управління справами Ради Народніх комісарів УСРР, 1933).

${ }^{20}$ Д. Богорад, Районная планировка Донеикого бассейна. (Киев: Гостехиздат, 1947), 116.

${ }^{21}$ Голодомор 1932-1933 років. Житомир. (Житомир: Волинь, 2008), 19.

${ }^{22}$ Архівні матеріали Харківської обласної організації “Меморіал” з Голодомору. Таблиця 13.
} 
кількість документів, які засвідчують, що в цьому місті масово вмирали ув'язнені більшовицькою владою хлібороби з багатьох регіонів республіки ${ }^{23}$.

У згаданих книгах реєстрацій актів громадянського стану також велика кількість свідчень про смерть дітей тамтешнього будинку немовляти. В багатьох 3 них незвичні для українців імена і прізвища: Бернард Шоу, Аркадій Бенеш, Дем'ян Бєдний... Так називали підкинутих голодними сільськими матерями безіменних дітей, які через якийсь час помирали - понад 700 таких жертв зафіксовано документами цього закладу. Зрозуміло, що абсолютна більшість 3 них не були від народження міськими жителями.

Що ж до кількості жертв Голодомору, то названі автори обгрунтовують свої розрахунки чинниками як внутрішньої міграції (тобто механічного відпливу населення з сіл у міста в кількості 3.388 тис. осіб за 1927-1938 рр.), так і зовнішньої, яку оцінюють у розрізі дев'яти потоків:

1) вивезення ув'язнених за межі республіки в 1928-1938 pp.

2) виселення “куркулів” за межі УСРР у 1930-1933 pp.

3) вимушена міграція за межі республіки в 1929-1933 pp.

4) організовані сільськогосподарські переселення в інші республіки впродовж 1927-1929 pp.

5) лепортація поляків і німців у Казахстан 1936 р.

6) еміграція євреїв за межі республіки в 1928-1938 pр.

7) організований набір робочої сили з сільської місцевости на новобудови за межами України в 1935 - 1938 рр.

8) переселення селян в Україну з Білорусії та Росії впродовж 1933-1934 pp.

9) виселення куркулів із Середньої Азії в УСРР в 1931 p.

Можна було б сприйняти такий підхід цієї групи дослідників, якби вказані новації щодо створення методики підрахунку жертв Голодомору 1932-1933 років спиралися на бездоганність статистики, на яку вони посилаються. Однак, на нашу думку, вона не дає можливости найповніше оцінити втрати сільського населення УСРР, оскільки автори охопили великий період, протягом якого й досі не реконструйовані всі події, які впливають на загальний підрахунок. За таких обставин невиправдано брати за базові дані результати Всесоюзного перепису населення 1926 р., оскільки до 1 січня 1932 р., тобто початку Голодомору, населення УСРР не лише значно збільшилося за рахунок природного приросту, але й через великий наплив робочої сили з-поза меж їі, в результаті чого загальна кількість його на вказану дату становила 32,68 млн осіб, що засвідчено тоді ще незаангажованою офіційною статистикою.

Крім того, помилкою є і поклики на дані Всесоюзного перепису 1939 р. по УРСР. Він не тільки не дає можливості визначити міграційні потоки населення через відсутність відповідного запитання, як це було в переписах 1897 i 1926 років, а й грішить істотними неточностями в підрахунках. Скажімо, за

${ }^{23}$ ДАЗО, ф. 5593, оп. 13, спр. 276, 313-317, 321. 
ISSN 2078-6077. Наукові зошити історичного факультету Львівського університету. 2020. Випуск 21. Proceedings of History Faculty of Lviv University. 2020. Issue 21.

офіційними документами більшовицької влади подається, що на початок 1939 p. в Україні нараховувалося 30.946.218 осіб ${ }^{24}$. Зовсім іншу картину репрезентуе начальник Управління народногосподарського обліку УРСР Рябичко в своїй таємній доповідній на ім'я голови Ради народних комісарів УРСР Коротченка від 2 лютого 1939 р.: “всього за переписом 1939 року ми маємо 29,4 млн. осіб”, а контрольний обхід через три тижні виявив додатково по республіці лише 17553 незареєстрованих раніше громадян ${ }^{25}$.

Як бачимо, понад півтора мільйона населення УСРР в 1939 р. було приписано, а це не дає можливости одержати правильні висновки. Що ж стосується поданих з Москви даних перепису 1937 р., який узагалі був засекречений, то в порівнянні 3 первинними документами, що лежать у Києві ${ }^{26}$, цифра, за нашими підрахунками, збільшена на 532 тисячі осіб - до 28.387.60927.

Проте скориговані офіційні дані якраз перепису 1937 р. дають можливість вийти на кількість населення УСРР на 1 січня 1934 р., що $€$ ключем до визначення кількості втрат у 1932-1933 роках. Тож коли від уточненої за порайонними результатами цифри кількости населення на січень 1937 р. в 27.851 тисячі осіб відняти кількість приросту в 1934 р. (88,2 тис. осіб), 1935 (417,2 тис.) i 1936 (533,7 тис.) - усього $1.039,1$ тис., то маємо станом на 1 січня 1934 р. 26.812 тисяч осіб. А мало бути 33.933.400: до кількости населення станом на 1.1.1932 року в 32.680,700 додасмо народжених у 1932 - 1933 роках в кількості 1.252,700. Різниця, отже, на 1 січня 1934 р. $7.121,400$ !

Однак такий підхід названа вище українсько-американська група істориків і демографів відкидає, намагаючись довести насамперед нереальність кількости населення УСРР станом на 1 січня 1932 р. в 32, 68 млн осіб, хоч це засвідчено і архівними, і опублікованими документами тодішньої влади. 3 цією метою зазначений колектив уповноважив доктора економічних наук Н. Левчук виступити зі спеціяльною статтею проти аргументів автора цих рядків, яка винесла ось такий вердикт: “Проведений аналіз “нової” концепції підрахунку втрат України від Голодомору, викладеної у статті В. Сергійчука, свідчить про некоректне використання статистичних даних, при якому обчислення "підлаштовуються" під заздалегідь озвучену цифру у 7 млн втрат, а також про серйозні методичні проблеми в розрахунку"28.

\footnotetext{
${ }^{24}$ Правда, (1939).

${ }^{25}$ Центральний державний архів вищих органів влади та управління України (далі ” ЦДАВО), ф. 2, оп. 12, спр. 70, арк. 5, 7.

${ }^{26}$ Центральний державний архів громадських об’єднань України (далі “ ЦДАГО), ф 1, оп. 20, спр. 7163, арк. 24-46.

${ }^{27}$ Всесоюзная перепись населения 1937 года. Краткие итоги. (Москва: Институт истории CCCP, 1991), 58.

${ }^{28}$ Н. Левчук, “До питання про “старі”та “нові” підходи до оцінки втрат населення України внаслідок Голодомору 1932-1933 рр.”, Украӥнський історичний журнал, № 2, (2018): 192.
} 
Така заява змушує автора цих рядків пояснити читачам, тим паче, що стаття Н. Левчук подана як дискусійна. I перше, що впадає в око: відкидаючи цифру в 32,68 млн населення УСРР станом на 1 січня 1932 р., пані Левчук не вказує своєї на цю дату. А це принципово, адже саме кількість населення УСРР станом на 1 січня 1932 i 1934 років іє найважливішим завданням дослідників, коли маємо встановити втрати від Голодомору 1932-1933 років.

Як можна зрозуміти Н. Левчук, вона зі своїми однодумцями не ставить перед собою завдання встановити ці дві цифри - головне для згаданої “українськоамериканської групи” піддати сумніву цифру 32,68 млн станом на 1 січня 1932 р. як базову для розрахунку втрат від Голодомору 1932-1933 років. При цьому поважна докторка економічних наук так поспішає оголосити про нездалість методики підрахунку автора цих рядків, що не помічає, як видає бажане для неї за дійсне. Наприклад, вона, не переглянувши уважно цитований “Довідник 3 основних статистично-економічних показників господарства районів Київської области. - Харків, 1933”, вдається до всіляких здогадок, цитуючи, приміром, застереження упорядників: “Зважаючи на незадовільний стан обліку в ряді наших установ.... ми не можемо гарантувати цілковитої певности та повноти показників, уміщених у довіднику".

I при цьому Н. Левчук замовчує, що в цьому та однотипних збірниках по інших областях вміщено не лише дані про кількість населення станом на 1 січня 1932 р., а й сотні сторінок статистичних звітів про те, як виконувались різні народногосподарські плани, в тому числі в перші місяці 1933 р., зокрема, про завдання зі здачі хліба державі в першому кварталі того року. Як мені видається, саме про вирогідність цих показників висловлювали своє застереження упорядники, а не про кількість людности, яка вже фігурує від грудня 1931 р. в архівних документах і врахована під час утворення областей у лютому 1932 р.: усього - 32.548,7 тис., міського - 7.032,9 тис., сільського - 25.515,8 тис. $\left(78,4\right.$ \%) ${ }^{29}$.

Так от, у кожному з виданих у Харкові управлінням справами Раднаркому УСРР 8 довідників з основних статистично-економічних показників господарства районів відповідних областей і Автономної МСРР перший розділ “Територія та населення" супроводжується спеціяльним поясненням до таблиць: “Відомості про територію та населення складено за станом на 1 січня 1932 року за матеріялами Центральної Адміністративно-Територіяльної Комісії при ВУЦВК” у, що їх одержано від районних виконавчих комітетів"з30. У цілому ж населення УСРР на той час, згідно з ними, нараховувалося $32.680,7$ тисячі осіб населення: міського - 7.127,7 тисячі, сільського - 25.553,0 тисячі ${ }^{31}$.

${ }^{29}$ ЦДАВО, ф. 539, оп. 10, спр. 80, арк. 185.

${ }^{30}$ Довідник з основних статистично-економічних показників господарства районів Київської области. (Харків, 1933), 5.

${ }^{31}$ Там само, 8. 
ISSN 2078-6077. Наукові зошити історичного факультету Львівського університету. 2020. Випуск 21. Proceedings of History Faculty of Lviv University. 2020. Issue 21.

З усього видно, ці дані були стверджені обліком міської і сільської людности, які проводилися в 1931 р. Скажімо, в архівних фондах Наркомату праці УСРР збереглися дві об'ємні теки листування з райвиконкомами про підготову і перебіг цієї важливої роботи в сільській місцевості. 3 нього виходить, що через запізнення 3 друком спеціяльних бланків, які надійшли на місця лише в жовтні, облік затягнувся, відтак його попередні результати підбили фактично станом на 2 грудня 1931 р., об'єднавши з даними тодішнього міського перепису. За нашими підрахунками, кількість населення УСРР на вказану дату становила 31.843.376 осіб (без Молдавської АСРР).

Коли ж надійшли всі дані, то й з'явилася цифра в 32.680 .700 осіб, яку оформили станом на 1 січня 1932 р. При цьому, випускаючи на початку 1933 р. довідники, врахували адміністративно-територяальні зміни, які сталися в лютому 1932 p. через створення нових областей.

Цю цифру визнає і діяспорний дослідник С. Сосновий, який до Другої світової працював у Держплані УРСР. У своїй статті “Правда про голод на Україні в 1932-33 роках" він, зокрема, зазначав: “Хоч як большевики заперечували наявність голоду на Україні, проте в двох надрукованих офіційних джерелах наведено цифри населення на 1 січня 1932 р. і на 1 січня 1933 р., які, стверджуючи факт загибелі з голоду значної кількости населення, в той же час дозволяють уточнити, скільки загинуло в 1932 р. і скільки в 1933 p.

Перше джерело - “Довідник з основних статистично-економічних відомостей”, виданий у 1933 р. За цим довідником на 1.1. 1932 р. в Україні було 32.680.700 душ (цифра цілком збігається з нашими обрахунками населення на цю дату, оскільки при ії обчисленні управління справами виходило з того відсотку приросту людности, що й ми, а саме 2,3 відсотка.

Друге джерело - це виданий 1935 р. Управлінням народно-господарського обліку УСРР довідник "Народне господарство УСРР". В цьому довіднику наводиться цифра населення на 1.1.1933 р. і складає вона 31.901 .500 душ"32.

Приймаючи щорічний природний приріст населення в 2,36 відсотка (ця цифра була зафіксована в 1924-1927 роках) за даними виданого в 1939 р. в Харкові “Збірника статистично-економічних відомостей про сільське господарство України”, С. Сосновий писав: “ми, за формулою складних відсотків, на 1. січня 1932 року мали 32.680.700 душ, на 1 січня 1933 року повинні були мати 33.406.100душ, а на 1.січня 1934 року - 34.258.000 душ.

Коли б населення в 1932-1933 роках не зменшувалось і розмножувалось і надалі такими темпами, як у 1924-27 роках - на 1. січня 1939 р. ми б мали 38.426.000 населення. В дійсності ж на 17 січня 1939 р. (час перепису) кількість населення в Україні без західних областей становила лише 30.960.200 душ.

Отже, виходить, що нестача населення на Україні внаслідок голоду 19321933 років становить 7.465.000 осіб”з3. (С. Сосновий не знав, що перепис по

\footnotetext{
32 Українські вісті, Ч. 11, (Новий Ульм, 1950).

${ }^{33}$ Там само.
} 
УРСР у 1939 р. сфальсифікований на 1,5 мільйона осіб, відповідно він не міг вивести остаточної реальної цифри втрат. - B. C.).

На жаль, згаданий “українсько-американський колектив демографів”, який узяв на себе місію визначати методику підрахунку втрат від Голодомору 1932 1933 років, фактично не обізнаний не тільки з матеріялами повоєнної української діяспорної преси, а й 3 первинними документами українських архівів, відтак його “новації” відірвані від реальних міграційних процесів, що тоді відбувалися, і не дадуть позитивного результату.

Скажімо, ніякими документами не підкріплюється твердження про безповоротний виїзд трьох мільйонів українських селян до Росії під час Голодомору. Документи свідчать про те, що голодних українських селян з теренів Росії намагалися відправити додому ще з початку літа 1932 р. - після сумнозвісного листа Сталіна до Молотова й Кагановича від 18 червня 1932 р., мовляв, “десятки тисяч українських колгоспників" блукають европейською частиною СРСР і “розкладають нам колгоспи своїми скаргами і скигленням”34.

Уже тоді з Росії виганяли не лише голодних селян, а й безпритульних українських дітей, які втратили батьків. Так, 17 липня 1932 р. московська міліція відправила до Києва 178 безпритульних дітей, яких виловили на вокзалах. А 22 липня 12 дітей було прислано до Конотопа з Калуги під тим приводом, що вони не розмовляють російською мовою, хоч це не відповідало дійсності ${ }^{35}$.

Зрозуміло, що широкомасштабне зачищення російських територій від голодних українців розпочалося після сумнозвісної постанови ЦК ВКП (б) і Раднаркому СРСР від 22 січня 1933 р. Микола Міняйло з Костянтинівки на Мелітопольщині згадував: "У січні 1933 р. під час шкільних канікул поїхав він до Курської області, звідки писали, що там голоду немає, там він у людей набрав трохи картоплі i хліба, але побачив сани з працівниками НКВС, які робили облаву на українців i гнали їх назад до України, хлопцю вдалося сховатися, але до двору зайшли три співробітники НКВС, наказали зібрати речі та привезли до залізничної станції. У залі було людей, як оселедців у бочці. Майже всю ніч люди стояли, вранці їх посадили на поїзд, у кожному вагоні знаходився співробітник НКВС. На кожній із зупинок з вагонів виносили померлих... Як тільки переїхали умовний кордон 3 Росією, охоронці залишили поїзд”з6.

Станом уже на 14 лютого 1933 р. було затримано 31.783 особи, з яких 28.351 повернуто в місця їхнього проживання, а 3.434 притягнуто до відповідальности, 579 відібрано, щоб скерувати до Казахської АСРР. А до початку березня 1933 року вже було затримано 219,5 тисячі осіб, з яких 186,6 тисячі повернуті додому. На початок березня 1933 р. було затримано 219,5 тис. осіб, з яких 186,6 тис. повернули в рідні місця, в тому числі й на Кубань ${ }^{37}$.

${ }^{34}$ Сталин и Каганович. Переписка. 1931-1936. (Москва, 2001), 179.

35 Державний архів Київської області (далі “ ДАКО), ф. 144, оп. 1, спр. 58, арк. 155-156.

${ }^{36}$ Голодомор 1932-1933: запорізький вимір. (Запоріжжя: Просвіта, 2008), 104.

${ }^{37}$ С. Кропачев, Масштабы демографических потерь СССР Начало 1930-х-середина 1940-х годов. Проблемы отечественной истории и историографии. (Краснодар: Экоинвест, 2010), 8. 
ISSN 2078-6077. Наукові зошити історичного факультету Львівського університету. 2020. Випуск 21. Proceedings of History Faculty of Lviv University. 2020. Issue 21.

Масштаби примусового повернення голодних українських селян з Росії були такими великими, що політбюро ЦК КП (б) У змушене було ухвалити 3 березня 1933 р. постанову “О крестьянах, возвращающихся в свои села”, де передбачено заходи, як використовувати так званих поворотців:

"Считать необходимым бедняков и середняков, возвращающихся в свои села, хозяйственно устроить - путем:

1. Принятия части из них в колхоз.

2. Отведения свободных участков земли.

3. Переселения в другие районы, где ощущается острая нужда в рабочей силе и где еще есть излишки земли.

б) В отношении возвращающихся кулаков - считать необходимым организацию принудительного труда.

в) Поручить СНК практически разработать вопрос о порядке и формах организации полупринудительного труда возвращающихся кулаков" 38 .

Скільки було повернуто примусово до України з літа 1932 до осені 1933 р. і скільки з них лягло в сиру землю - ніхто не порахував. Можемо лиш зазначити: заборону політбюро ЦК КП(б)У про виїзд за межі УСРР, яку відмінено 2 жовтня 1933 р. - після того, як уповноважений Наркомату шляхів сполучення в УСРР Лавріщев звернувся з відповідним запитом до української влади ${ }^{39}$.

Паралельно з цим до УСРР зі сходу й півночі спрямовувався величезний потік робочої сили, яка заповнювала вакансії на новобудовах.Так, член колегії Наркомпраці Худокормов 8 січня 1932 р. доповідав Раднаркому УСРР про те, що для забезпечення промисловості й будівництва робочою силою в 1932 p. необхідно мати додатково близько 600 тисяч осіб, у тому числі 130 тисяч для шахт Донбасу. Для цього із УСРР планувалося завербувати 44 тисячі, а 3 РСФРР - 64 тисячі ${ }^{40}$.

Потребу в 130 тисячах кваліфікованих робітниках планували покрити за рахунок підготови господарським способом 70 тисяч, а також через вербунок 20 тисяч з районів УСРР і 40 тисяч - з РСФРР 41.

План вербування по тресту “Сталінвугілля” на березень - травень 1932 року передбачав: 6.575 , у тому числі з УСРР -2.375 , ЦЧО - 800, Татарстану 2.500, БСРР - 900. За березень, квітень і 20 днів травня завербовано лише 1.010 чоловік, у тому числі, з УСРР - 479, ЦЧО - 309, Татарстану - 212 і БСРР $-10^{42}$.

Традиція завезення робочої сили з-поза меж УСРР набула особливого розвитку з початком Голодомору. Як засвідчують документи, “наиболее

\footnotetext{
${ }^{38}$ ЦДАГО, ф. 1, оп. 16, спр. 19, арк. 72-72 зв.

${ }^{39}$ ЦДАГО, ф. 1, оп. 6, спр. 323, арк. 269.

${ }^{40}$ ЦДАВО, ф. 539, оп. 10, спр. 73, арк. 24.

${ }^{41}$ Там само, арк. 25.

${ }^{42}$ ЦДАГО, ф. 1, оп. 20, спр. 5315, арк. 16.
} 
устойчивыми оказались группы вербованных из Западной области и Тат. Республики... По выполнению плана Украина оказалась на последнем месте"43.

3 цього приводу 23 січня 1932 р. Косіора повідомляли: “Сейчас мы наблюдаем такую картину: старые шахтеры из Белоруссии и Центральной Черноземной области, которые в последние годы засели в деревне, снимаются с "якоря" со всеми своими пожитками, семействами и сватами и едут в Донбасс, и как будто оседают в Донбассе всерьез и надовго"44.

Природно, на це звернули увагу і вже 10 квітня 1932 р. члени і кандидати в члени політбюро ЦК КП(б)У розглядали доповідну записку щодо необхідности “для пополнения убыли в рабочей силе произвести новую вербовку рабочей силы для Донбасса в количестве 20 тыс. человек. Из них 10 тыс. в пределах Украины, а остальные 10 тыс. в пределах РСФСР, о чем просить ЦК ВКП (б)" ${ }^{45}$.

Цю тенденцію - вербувати будь що за межами УСРР - підхоплювали і в низах. Так, керівники хімічного заводу імені Петровського, якому в серпні 1932 p. не вистачало 2.795 робітників, просили вищі інстанції “отвести иные районы на Украине, обязав районные организации обеспечить отпуск людей с колхозов, и поставить вопрос перед ЦК ВКПб и Наркомтрудом о выделении районов в РСФСР и Белорусской ССР для организованного набора рабочей силы"“6.

Водночас набуло поширення таке явище, як самоплив робочої сили, в тому числі і з-поза меж УСРР, і на інших великих підприємствах. Наприклад, за 8 місяців 1932 р. на будівництво “Азовсталі” прибуло самопливом 7.849 робітників і тільки 3.002 було завербовано ${ }^{47}$.

Вербування робочої сили 3-поза меж УСРР стояло на першому місці і в учасників спеціяльної наради щодо “упорядочения дела вербовки рабсилы для угольной промышленности Донбасса" при Донецькому обкомі КП (б) У в січні 1933 року, на яку запрошувалися "представители НКТруда СССР и УССР, Главтопа, угольных трестов Донбасса и их уполномоченных по областям, представителей обкома ЦЧО, Белоруссии, Татарии, Киевщины, Винницы..."

Ініціаятиву в цьому плані доручалося проявляти місцевим “смотрящим Москви”. Так, 4 серпня 1933 р. секретар Дніпропетровського обкому Хазанов просив Кагановича й Косіора “выделить дополнительные лимиты на ввоз квалифицированной и неквалифицированной рабсилы из других областей и республик Союза в количестве до 36.000 человек (желательно из Татарской, Башкирской и Белорусской республік”) ${ }^{49}$.

${ }^{43}$ ЦДАГО, ф. 1, оп. 20, спр. 5588, арк. 5.

${ }^{44}$ Там само, арк. 9.

${ }^{45}$ ЦДАГО, ф. 1, оп. 20, спр. 5313, арк. 84.

${ }^{46}$ ЦДАГО, ф. 1, оп. 20, спр. 5326, арк. 8-9.

${ }^{47}$ ЦДАГО, ф. 1, оп. 20, спр. 5599, арк. 5.

${ }^{48}$ ЦДАГО, ф. 1, оп. 20, спр. 6237, арк. 33.

${ }^{49}$ ЦДАГО, ф. 1, оп. 20, спр. 6241, арк. 31. 
ISSN 2078-6077. Наукові зошити історичного факультету Львівського університету. 2020. Випуск 21. Proceedings of History Faculty of Lviv University. 2020. Issue 21.

А 24 липня 1933 р. бюро обкому ухвалило: “Учитывая, что внутриобластные ресурсы рабочей силы не могут покрыть всех потребностей заводов и новостроек в области, просить ЦК ВКПб, ЦК КПбУ и Наркомтяжпром оказать заводам и новостройкам нашей области и в первую очередь заводам Петровского и Дзержинского путем завоза рабсилы из других областей и краев Союза, с тем, чтобы Наркомтруд прикрепил для вербовки Татарию и Башкирию и выделил дополнительные лимиты на квалифицированную и неквалифицированную рабсилу"50.

Той же секретар Дніпропетровського обкому партії Хазанов 25 вересня 1933 р., повідомляючи Кагановича й Постишева про те, що на будовах регіону працює до 25 тисяч завербованих колгоспників з Середньої Волги, просив дозволити "на заработанные ими деньги в организованном порядке закупить хлеб в период разрешения свободной торговли хлебом"

Через три тижні Дніпропетровський обком просить Кагановича дозволити “выделить дополнительные лимиты на ввоз в область рабочей силы на 36.000 чел., желательно из Татарской, Башкирской и Белорусской республік"52.

А 3-го листопада 1933 року бюро розглянуло питання підготоки до прийому на заводи області завербованої робочої сили на Середній Волзі. Висловлено стурбованість, що Дніпрокомбінат не освоїв наряди на вербунок в цьому російському регіоні на 12 тисяч робітників, заводи імени Дзержинського i Петровського, трест Дзержинськбуд - по 2 тисячі, трест “Руда", Кривбасбуд ” по 4 тисячі. Незадовільно освоювали додаткові фонди в Самарському краї також Нікопольбуд (наряд на 1000 робітників), Криворіжжякоксохіммонтаж (1000), Запоріжжякоксохімбуд (2000) $)^{53}$.

Це питання, з усього видно, було і на контролі в Кремлі, оскільки 5 липня 1932 р. помічник Сталіна Бажанов телеграфував Косіорові, щоб “мобилизовать в августе 25.000 чел., в сентябре 29.000 чел. (Татарии, Черноземной, Белоруссии, Украине и в Западной области" 54 .

Відтак на місцях у російській глибинці намагалися виконати наряди Москви. Скажімо, секретар обкому Центрально-Чорноземної області Малинов телеграфував секретареві ЦК КП (б) У Терехову: “Воздействуйте на тресты угля Украины немедленном переводе уполномоченному Главтопа Воронеж денег отправки завербованных рабочих тчк"55.

Зрозуміло, ці “підказки” з Росії негайно підштовхували керівників промислових підприємств України до активних дій: так, трест “Сталінвугілля” у грудні 1932 p. розіслав 516 вербувальників, з яких по Україні лише $40^{56}$.

\footnotetext{
${ }^{50}$ Державний архів Дніпропетровської області (далі “ ДАДО), П-19, оп.1, спр. 525, арк. 49 зв.

${ }^{51}$ ЦДАГО, ф. 1, оп. 20, спр. 6243, арк. 71.

52 ЦДАГО, ф. 1, оп. 20, спр. 6241, арк. 33.

53 ДАДО, П-19, оп. 1, спр. 529, арк. 123 зв.

${ }^{54}$ ЦДАГО, ф. 1, оп. 20, спр. 5315, арк. 91.

55 Там само, арк. 105.

${ }^{56}$ Там само, арк. 120.
} 
Подібне було і в інших промислових регіонах, про що свідчить механічний рух населення Харківської області з-поза меж УСРР ${ }^{57 *}$

\begin{tabular}{|l|l|l|l|l|}
\hline Республіки & \multicolumn{1}{|c|}{$\begin{array}{c}\mathbf{1 9 3 2} \\
\text { Прибуло / } \\
\text { Вибуло }\end{array}$} & $\begin{array}{c}\text { 1934 } \\
\text { Прибуло / } \\
\text { Вибуло }\end{array}$ & $\begin{array}{c}\text { 1935 } \\
\text { Прибуло / } \\
\text { Вибуло }\end{array}$ & $\begin{array}{c}\text { 1936 } \\
\text { Прибуло / } \\
\text { Вибуло }\end{array}$ \\
\hline РСФРР & $92485 / 73206$ & $71880 / 57053$ & $75102 / 70715$ & $101727 / 79157$ \\
\hline Каз. АСРР & $71440 / 417$ & $442 /-$ & $663 / 339$ & $697 / 479$ \\
\hline Кир. АСРР & $168 / 169$ & $73 /-$ & $183 / 87$ & $136 / 101$ \\
\hline БСРР & $2705 / 2216$ & $1921 / 1717$ & $2778 / 2685$ & $2720 / 2388$ \\
\hline ЗСФРР & $2201 / 1805$ & $2087 / 1869$ & $3317 / 2318$ & $3479 / 3328$ \\
\hline Азер. СРР & $899 / 792$ & $599 / 616$ & $1321 / 855$ & $1381 / 1516$ \\
\hline Вірм. СРР & $95 / 60$ & $152 / 141$ & $372 / 269$ & $489 / 393$ \\
\hline Груз. СРР & $1155 / 926$ & $1281 / 1030$ & $1613 / 1191$ & $1609 / 1349$ \\
\hline Узб. СРР & $443 / 369$ & $435 / 312$ & $582 / 463$ & $639 / 630$ \\
\hline Тадж. СРР & $75 / 61$ & $97 / 37$ & $176 / 79$ & $146 / 102$ \\
\hline Туркм. СРР & $189 / 926^{*}$ & $112 / 138$ & $322 / 177$ & $441 / 84^{*}$ \\
\hline
\end{tabular}

Отже, голодні українські селяни, які кинулись до міста, аби влаштуватися на роботу з метою рятувати від голоду свої родини, до уваги не бралися, бо робоча сила шукатиметься на стороні - на шахти тресту “Кадіїввугілля” у жовтні 1932 р. прийняли на роботу 859 осіб, з них з УСРР - тільки $123^{58}$.

Переселенці з Росії, до речі, перебиралися не одинаками, а з родинами, потім закликали родичів, знайомих. Так, керівник Української контори “Нафтопровідскладбуд” Верховський, якого перекинули з Липецька, привіз зі собою таких працівників: Я. Л. Бухштабера, А. Б. Аксельруда, А. А. Гурвича, 3. І. Шелехову (дружина), В. М. Карпана, Г. Д. Доліна, Ф. М. Цукерман (сестра), М. І. Шварцман, Я. І. Бердичевського, Ю.Г. Негруша, Н. М. Каца та інших ${ }^{59}$.

Точну кількість завезених до УСРР у 1932-1936 роках ми могли б легко визначити, аби в переписі 1937 р. залишалася, як у 1926, графа “де народився”, але ії Сталін власноручно викреслив. Не було ії і під час наступного перепису $1939 \mathrm{p}$.

Зрештою, окремо стоїть питання про достовірність статистики смертей, на котру посилаються наші демографи. Не всюди місцеві керівники, налякані можливістю відповідальности за високий процент смертности, насмілювалися показувати справжню картину цієї трагедії. Щоб приховати справжній стан зі смертністю населення, в багатьох районах вирішили замовчувати той факт. Скажімо, 27 квітня 1933 р. бюро Брацлавського райкому КП(б)У Вінницької

${ }^{57}$ ДАХО, ф. Р-5231, оп. 2, спр. 2, арк. 5-5 зв.; спр. 10, арк. 1-1 зв.; спр. 18, арк. 7-7 зв.; спр. 27, арк. 7-7 зв.

* Йдеться, очевидно, про повернення частини так званих баїв, що були вислані в південні райони УСРР для запровадження бавовництва. - В. С.

${ }^{58}$ ЦДАГО, ф. 1, оп. 20, арк. 42-43.

${ }^{59}$ ЦДАВО, ф. 2, оп. 12, спр. 1, арк. 143-147. 
ISSN 2078-6077. Наукові зошити історичного факультету Львівського університету. 2020. Випуск 21. Proceedings of History Faculty of Lviv University. 2020. Issue 21.

Зрештою, окремо стоїть питання про достовірність статистики смертей, на котру посилаються наші демографи. Не всюди місцеві керівники, налякані можливістю відповідальности за високий процент смертности, насмілювалися показувати справжню картину цієї трагедії. Щоб приховати справжній стан зі смертністю населення, в багатьох районах вирішили замовчувати той факт. Скажімо, 27 квітня 1933 р. бюро Брацлавського райкому КП(б)У Вінницької області, визнавши, "що голодування набирає дійсно широкого розміру, як по кількості сіл, так і по розміру в кожному селі і має тенденцію поширення", водночас ухвалює: "Вважати за неприпустиме факти реєстрації смерті по книжках ЗАГС окремими сільськими Радами “від голоду”, оскільки це ніким не встановлено. Запропонувати фракції райвиконкому дати сільським Радам відповідні вказівки по цьому"б0.

Безумовно, така політика влади дезорієнтувала працівників сільрад, які реєстрували факти смертей і спричинилася до того, що в багатьох місцях почали не тільки фальсифікувати діягнози, а й приховувати масовість цієї трагедії. Відтак 28 серпня 1933 р. Вінницьке обласне УНГО наголошувало про несвоєчасну звітність про рух населення на місцях. Зокрема, вказувалося, що не здали звіти за травень-червень Бершадський, Гайсинський, Джулинський, Козятинський, Муровано-Куриловецький, Немирівський, Теофіпольський, Тиврівський, Чуднівський і Янушпільський райони. Водночас Бердичівський район надав неповноцінний статистичний матеріял за червень - 39 сільрад звітні матеріяли надійшли лише з 20. Подібна картина спостерігалася також і в Брацлавському (43 i 17), Заславському (58 і 41), Іллінецькому (48 і 19), Кам’янецькому (38 і 23), Козятинському (48 і 23), Копайгородському (37 і 9), Славутському (65 i 43), Старокостянтинівському (46 і 30), Тиврівському (33 і 16), Шаргородському (45 i 25$)^{61}$.

А Вінницька міськрада, до складу якої входили десятки навколишніх сіл, навіть у середині листопада 1933 р. не прозвітувала про рух населення в першому півріччі ${ }^{62}$.

На жаль, не збереглося подібних актових записів з Переорської сільради, керівники якої просили органи ЗАГСу “передати через посланого виконавця книгу записів про смерть, в котрі заявляється крайня необхідність"бз.

Оскільки така ж “крайня необхідність” виникла і в Полтавській, Станіславчицькій, Синюхино-Брідській та інших сільських радах Первомайського району тодішньої Одеської області, то свідоцтва про смерть почали виписувати на бланках документів про народження, одруження й розлучення ${ }^{64}$.

${ }^{60}$ Вінниччина, (1993).

${ }^{61}$ Державний архів Вінницької області (далі - ДАВО), ф. Р-2071, оп. 1, спр. 348, арк. 50.

${ }^{62}$ Там само, арк. 74.

${ }^{63}$ ДАВО, ф. Р-2071, оп. 1, спр. 355, арк. 78.

${ }^{64}$ Державний архів Миколаївської області (далі- ДАМО), ф. Р-5950, оп. 18, спр. 156, арк. 1453. 
Підтвердженням того, що звітні дані з місць були далеко неповними може служити документ про перевірку реєстрації смертей у Сквирському й Володарському районах Київщини, яка відбулася взимку 1933 р. Зокрема, доповідна записка заступника наркома охорони здоров'я УСРР Хармандар'яна до генерального секретаря ЦК КП(б)У Косіора від 6 червня 1933 р. констатує: "Безсумнівним слід вважати значно применшені цифри померлих, так як перевірка на місцях та ретельне дослідження місцевого матеряала свідчать про значно більші цифри: так по Сквирському району з 1.01 по 1.03 по звітним даним померло 802 чол., тоді як перевіркою встановлено на 15.011 .773 смертельних випадки, у Володарському районі на 1.03 говориться про 742 смерті, тоді як насправді до цього часу померло більше 3.000 чол." ${ }^{\prime \prime}$.

Що важливо: ознайомлення 3 документами, що збереглися в Державному архіві Київської области, засвідчує, що ніяких змін у звітність після виявлення спеціяльною перевіркою в 1933 р. недообліку смертей не було внесено, відтак і донині тодішня офіційна статистика не дає реального результату про втрати, які повинні були бути зареєстрованими за місцем проживання в 1932-1934 роках. Про це, зокрема, свідчать дані 3 наведеної нижче таблиці про кількість населення в районах Київської області станом на 1 січня 1932 і 1933 років, народжених у 1933, померлих тоді, в тому числі до 1 року, відтак залишок на 1 січня 1934, різниця за 1932-1933 роки, а також довідка про нездані щомісячні звіти сільрад ${ }^{66}$.

\begin{tabular}{|c|c|c|c|c|c|c|c|c|}
\hline Райони & $\begin{array}{l}1.1 .1932 \\
\text { тисяч } \\
\text { осіб }\end{array}$ & $\begin{array}{l}\text { 1.1.1933 } \\
\text { тисяч } \\
\text { осіб }\end{array}$ & $\begin{array}{l}\text { Нар. } \\
1933 \\
\text { року }\end{array}$ & $\begin{array}{l}\text { По- } \\
\text { мер- } \\
\text { ло } \\
1933 \\
\text { року }\end{array}$ & $\begin{array}{l}\text { В } \\
\text { тому } \\
\text { числі } \\
\text { до } 1 \\
\text { року }\end{array}$ & $\begin{array}{l}\text { 1.1.1934 } \\
\text { осіб }\end{array}$ & $\begin{array}{l}+- \\
1932- \\
1934\end{array}$ & $\begin{array}{l}\mathrm{He} \\
\text { одер- } \\
\text { жано } \\
\text { звіпів } \\
\text { від } \\
\text { сіль- } \\
\text { рад }\end{array}$ \\
\hline $\begin{array}{l}\text { Андрушів- } \\
\text { ський }\end{array}$ & 70,1 & 63.739 & $\begin{array}{l}1.13 \\
1 \\
\end{array}$ & 8.258 & 239 & 56.612 & -14.358 & 8 \\
\hline Бабанський & 95,9 & 74.321 & 892 & 9.124 & 310 & 66.089 & -29.811 & 18 \\
\hline Базарський & 33,2 & 26.672 & 543 & 1.862 & 103 & 25.353 & -7.847 & 10 \\
\hline Барані вський & 49,0 & 50.871 & 977 & 2.494 & 162 & 49.354 & -354 & 19 \\
\hline Барашів ський & 34,5 & 29.252 & 608 & 3.312 & 104 & 26.548 & -7.952 & 6 \\
\hline Баришівський & 85,3 & 71.270 & 893 & 9.344 & 260 & 62.819 & -22.481 & 14 \\
\hline $\begin{array}{l}\text { Боришпіль- } \\
\text { ський }\end{array}$ & 72,5 & 62.211 & 792 & 5.739 & 266 & 57.264 & -15.236 & 16 \\
\hline $\begin{array}{l}\text { Білоцерків- } \\
\text { ський }\end{array}$ & $144,0^{*}$ & 84.600 & 888 & 10.570 & 308 & 74.918 & -22.482 & 80 \\
\hline
\end{tabular}

${ }^{65}$ ЦДАГО, ф. 1, оп. 20, спр. 6276, арк. 2.

${ }^{66}$ Довідник з основних статистично-економічних показників господарства районів Київської области УСРР. (Харків, 1933), 6-8; ДАКО, ф.235, оп. 1, спр. 21, арк. 1-108.

*Включено і населення Білої Церкви, якого тоді нараховувалося 46,6 тисячі осіб. 
ISSN 2078-6077. Наукові зошити історичного факультету Львівського університету. 2020. Випуск 21. Proceedings of History Faculty of Lviv University. 2020. Issue 21.

\begin{tabular}{|c|c|c|c|c|c|c|c|c|}
\hline $\begin{array}{l}\text { Богуслав- } \\
\text { ський }\end{array}$ & 140,6 & 106.739 & 1.196 & 16.118 & 298 & 91.917 & -48.783 & 0 \\
\hline Бородянський & 45,3 & 35.493 & 454 & 2.446 & 80 & 33.501 & -11.799 & 14 \\
\hline $\begin{array}{l}\text { Брусилів- } \\
\text { ський }\end{array}$ & 83,5 & 74.581 & 1.115 & 5.702 & 225 & 69.994 & -15.306 & 5 \\
\hline Буць кий & 117,9 & 90.503 & 909 & 11.020 & 160 & 80.392 & -37.508 & 47 \\
\hline $\begin{array}{l}\text { Васильків- } \\
\text { ський }\end{array}$ & 95,3 & 83.751 & 974 & 8.022 & 238 & 76.703 & -18.597 & 36 \\
\hline $\begin{array}{l}\text { Вищедубе- } \\
\text { чанський }\end{array}$ & 35,4 & 33.445 & 557 & 2.068 & 117 & 31.934 & -3.466 & 4 \\
\hline Володарський & 51,7 & 34.815 & 309 & 8.335 & 148 & 26.789 & -24.911 & 28 \\
\hline $\begin{array}{l}\text { Вол.- } \\
\text { Волинський }\end{array}$ & 56,6 & 49.983 & 1.108 & 3.256 & 176 & 47.835 & -8.765 & 28 \\
\hline $\begin{array}{l}\text { Гельм'язів- } \\
\text { ський }\end{array}$ & 55,1 & 42.198 & 491 & 8.800 & 202 & 33.889 & -21.211 & 7 \\
\hline $\begin{array}{l}\text { Городни - } \\
\text { цький }\end{array}$ & 30,5 & 26.719 & 881 & 997 & 118 & 26.603 & -3.897 & 32 \\
\hline Димерський & 41,3 & 38.858 & 540 & 1.684 & 107 & 37.714 & -3.586 & 3 \\
\hline $\begin{array}{l}\text { Смільчин- } \\
\text { ський }\end{array}$ & 62,7 & 57.032 & 1.728 & 2.943 & 220 & 55.817 & -6.883 & 23 \\
\hline Жашкі вський & 50,4 & 41.568 & 662 & 5.189 & 76 & 37.041 & -13.359 & 6 \\
\hline $\begin{array}{l}\text { Житомир- } \\
\text { ський }\end{array}$ & $112,0^{3 *}$ & 31.432 & 653 & 1.593 & 147 & 30.492 & -4.402 & 0 \\
\hline $\begin{array}{l}\text { Звенигородсь } \\
\text { кий }\end{array}$ & 87,2 & 55.738 & 500 & 8.400 & 95 & 47.838 & -39.362 & 11 \\
\hline $\begin{array}{l}\text { Златопіль- } \\
\text { ський }\end{array}$ & 50,5 & 39.669 & 341 & 4.871 & 107 & 35.139 & -15.361 & 2 \\
\hline $\begin{array}{l}\text { Золотоні- } \\
\text { ський }\end{array}$ & 91,6 & 62.664 & 864 & 5.640 & 172 & 57.888 & -33.712 & 8 \\
\hline Іванківський & 43,1 & 39.006 & 672 & 2.211 & 98 & 37.467 & -5.633 & 28 \\
\hline Кагарлицький & 58,1 & 49.077 & 642 & 5.784 & 163 & 43.935 & -14.165 & 7 \\
\hline Кам'янський & 122,4 & 101.821 & 1.245 & 11.212 & 294 & 91.854 & -30.546 & 14 \\
\hline Канівський & 87,2 & 64.200 & 840 & 8.903 & 112 & 56.137 & -31.063 & 47 \\
\hline Київський & $769,9^{\text {*** }}$ & 142.718 & 2.222 & 8.252 & 453 & 136.688 & -20.312 & 46 \\
\hline $\begin{array}{l}\text { Коростен- } \\
\text { ський }\end{array}$ & 84,3 & 58.029 & 1.403 & 4.331 & 234 & 55.101 & -29.199 & 8 \\
\hline $\begin{array}{l}\text { Коростишів- } \\
\text { ський }\end{array}$ & 49,3 & 48.686 & 1.153 & 1.874 & 172 & 47.965 & -1.335 & 10 \\
\hline Корсунський & 94,3 & 77.178 & 861 & 6.692 & 166 & 71.347 & -22.953 & 38 \\
\hline Лисянський & 66,5 & 51.252 & 536 & 8.990 & 126 & 42.798 & -23.702 & 12 \\
\hline Лугинський & 36,7 & 35.618 & 786 & 1.759 & 134 & 34.645 & -2.055 & 74 \\
\hline Макарі вський & 58,2 & 51.005 & 766 & 3.450 & 99 & 48.321 & -9.879 & 14 \\
\hline Малинський & 89,5 & 68.413 & 797 & 5.022 & 192 & 64.188 & -25.312 & 95 \\
\hline
\end{tabular}

** Включено і населення Житомира, якого тоді нараховувало 77,1 тисячі осіб.

****Включено і населення Києва, якого тоді нараховувало 612,9 тисячі осіб. 
ISSN 2078-6077. Наукові зошити історичного факультету Львівського університету. 2020. Випуск 21. Proceedings of History Faculty of Lviv University. 2020. Issue 21.

\begin{tabular}{|c|c|c|c|c|c|c|c|c|}
\hline $\begin{array}{l}\text { Мархлев- } \\
\text { ський }\end{array}$ & 49,4 & 50.143 & 916 & 2.034 & 153 & 49.025 & -375 & 80 \\
\hline $\begin{array}{l}\text { Монастири- } \\
\text { щенський }\end{array}$ & 72,4 & 61.887 & 1.143 & 8.664 & 301 & 54.366 & -18.034 & 20 \\
\hline Народицький & 41,5 & 39.638 & 695 & 1.532 & 101 & 38.801 & -2.699 & 9 \\
\hline $\begin{array}{l}\text { Нов.- } \\
\text { Волинський }\end{array}$ & 92,9 & 65.745 & 1.736 & 3.489 & 284 & 63.992 & -28.908 & 35 \\
\hline Обухівський & 80,7 & 69.445 & 674 & 8.195 & 128 & 61.924 & -18.776 & 14 \\
\hline Овруцький & 68,8 & 55.038 & 1.301 & 3.244 & 202 & 53.095 & -15.705 & 15 \\
\hline Олевський & 51,1 & 45.386 & 1.560 & 1.475 & 62 & 45.471 & -5.629 & 5 \\
\hline Оратівсь кий & 50,8 & 41.791 & 593 & 7.491 & 125 & 34.893 & -15.907 & 1 \\
\hline $\begin{array}{l}\text { Переяслав- } \\
\text { ський }\end{array}$ & 106,0 & 79.798 & 969 & 12.823 & 360 & 67.924 & -38.076 & 26 \\
\hline $\begin{array}{l}\text { Ім. } \\
\text { Петровського }\end{array}$ & 127,6 & $\begin{array}{l}108.38 \\
9 \\
\end{array}$ & 1.082 & 9.797 & 177 & 99.674 & -27.926 & 9 \\
\hline Плисківський & 56,3 & 45.995 & 556 & 7.975 & 108 & 38.576 & -17.724 & 16 \\
\hline $\begin{array}{l}\text { Погребищен- } \\
\text { ський }\end{array}$ & 70,4 & 60.174 & 884 & 7.477 & 123 & 53.581 & -16.918 & 101 \\
\hline $\begin{array}{l}\text { Попільнян- } \\
\text { ський }\end{array}$ & 96,8 & 85.351 & 969 & 11.101 & 180 & 75.219 & -21.581 & 41 \\
\hline Потіївський & 42,0 & 39.568 & 905 & 2.370 & 206 & 38.103 & -3.897 & 22 \\
\hline Пулинський & 36,7 & 31.246 & 953 & 1.811 & 194 & 30.388 & -6.312 & 5 \\
\hline $\begin{array}{l}\text { Радомишль- } \\
\text { ський }\end{array}$ & 67,0 & 47.396 & 873 & 2.974 & 158 & 45.295 & -21.705 & 38 \\
\hline Ржищівсь кий & 71,2 & 55.055 & 432 & 10.630 & 138 & 44.857 & -26.343 & 29 \\
\hline $\begin{array}{l}\text { Розважів- } \\
\text { ський }\end{array}$ & 43,5 & 36.383 & 572 & 3.492 & 183 & 33.463 & -10.037 & 12 \\
\hline $\begin{array}{l}\text { Рокитнян- } \\
\text { ський }\end{array}$ & 102,5 & 82.316 & 894 & $\begin{array}{l}10.95 \\
8\end{array}$ & 136 & 72.252 & -30.248 & 15 \\
\hline Ружинський & 103,8 & 89.723 & $\begin{array}{l}1.37 \\
2\end{array}$ & 12258 & 418 & 78.837 & -24.963 & 33 \\
\hline Скв ирський & 106,7 & 96.516 & 1.154 & 12801 & 302 & 84.869 & -21.831 & 20 \\
\hline $\begin{array}{l}\text { Словечан- } \\
\text { ський }\end{array}$ & 35,7 & 31.687 & 950 & 1.826 & 140 & 30.811 & -4.889 & 12 \\
\hline Смілянськи й & 130,0 & 87.029 & $\begin{array}{l}1.04 \\
8\end{array}$ & 9.884 & 245 & 78.193 & -51.877 & 5 \\
\hline $\begin{array}{l}\text { Ставищен- } \\
\text { ський }\end{array}$ & 65,9 & 51.106 & 604 & 10.179 & 132 & 41.531 & -24.369 & 8 \\
\hline Тальнівський & 108,6 & 91.688 & 1.023 & 8.774 & 120 & 83.937 & -24.663 & 45 \\
\hline $\begin{array}{l}\text { Таращан- } \\
\text { ський }\end{array}$ & 81,6 & 54.588 & 639 & 8.787 & 123 & 46.440 & -35.160 & 7 \\
\hline Тетіївський & 57,2 & 44.403 & 596 & 12.000 & 327 & 32.999 & -24.201 & 12 \\
\hline Троянівський & 49,3 & 42.969 & 956 & 4.326 & 199 & 39.599 & -9.701 & 6 \\
\hline Уманський & $144,0^{* * * * * *}$ & 77.527 & 677 & 9.279 & 197 & 68.925 & -34.575 & 13 \\
\hline
\end{tabular}

***** Включено і населення Умані, якого тоді нараховувало 40,5 тисячі осіб. 
ISSN 2078-6077. Наукові зошити історичного факультету Львівського університету. 2020. Випуск 21. Proceedings of History Faculty of Lviv University. 2020. Issue 21.

\begin{tabular}{|l|l|l|l|l|l|l|l|l|}
\hline Фастівський & 81,6 & 54.689 & 471 & 6.130 & 93 & 49.030 & -32.570 & 44 \\
\hline Хабнянський & 40,1 & 33.157 & 471 & 3.051 & 117 & 30.57 & -9.523 & 20 \\
\hline $\begin{array}{l}\text { Христиів- } \\
\text { ський }\end{array}$ & 57,2 & 46.021 & 545 & 4.284 & 109 & 42.282 & -14.918 & 27 \\
\hline Черкаський & $147,5^{\text {вняня⿻ }}$ & 75.833 & 505 & 8.056 & 121 & 68.282 & -29.118 & 20 \\
\hline $\begin{array}{l}\text { Черняхів- } \\
\text { ський }\end{array}$ & 59,6 & 54.356 & 1.050 & 3.089 & 199 & 52.317 & -7.283 & 34 \\
\hline $\begin{array}{l}\text { Чигирин- } \\
\text { ський }\end{array}$ & 92,7 & 84.185 & 957 & 6.077 & 261 & 79.065 & -13.665 & 0 \\
\hline $\begin{array}{l}\text { Чорнобаїв- } \\
\text { ський }\end{array}$ & 97,7 & 83.235 & 1.075 & 7.985 & 284 & 76.325 & -21.375 & 14 \\
\hline $\begin{array}{l}\text { Чорнобиль- } \\
\text { ський }\end{array}$ & 70,5 & 58.268 & 1.172 & 2.138 & 179 & 57.302 & -13.198 & 38 \\
\hline Шполянський & 99,3 & 90.946 & 726 & 7.781 & 194 & 73.891 & -25.401 & 8 \\
\hline Ярунський & 38,7 & & & & & & & \\
\hline Разом село & 5257,8 & 4.493 .797 & & & & 4.086900 & -1.396 .961 & 1.677 \\
\hline Міста & $1.090,0$ & 996.650 & 13.198 & 51.296 & 3.160 & 958.552 & -131.448 & \\
\hline Усього & 6347,8 & 5.490 .447 & & & & 5.045 .452 & -1.489 .709 & \\
\hline
\end{tabular}

У Київській області, як бачимо, абсолютні втрати в 1932-1933 роках щонайменше 1.489.709 осіб (не здано в 1933 р. 1677 місячних звітів з окремих сільрад, що значно применшило смертність). Розрахунки наших опонентів, послідовності наукового пошуку яких ми не бачимо, щодо втрат Київщини сягають лише $1.110,8$ тис $^{67}$.

Коли більшовицька влада усвідомила масштаб Голодомору, то вона почала ховати первинні документи. Так, 13 квітня 1934 р. Одеський облвиконком ухвалив рішення вилучити книги актових записів за 1932-1933 рік і передачу їх на зберігання до таємних частин райвиконкомів, "зі злочинним обліком народження та смертей в сільрадах в результаті роботи “чужих елементів"

Подібну директиву до міськрайвиконкомів 20 квітня 1934 р. також розіслала влада Харківської области, яка вимагала "очистить сельсоветы от классововраждебных и чуждых элементов, установив регулярное наблюдение за делом регистрации актов"69.

Цей документ гласив: “Все книги регистрации смертей за 1933 год и за 1932 год, начиная с ноября месяца Областной исполнительный комитет требует изъять из сельсоветов и передать для хранения в секретную часть райисполкомов" ${ }^{\text {”. }}$

\footnotetext{
***** Включено і населення Черкас, якого тоді нараховувало 39,9 тисячі осіб.

****** Звітних даних про природний рух населення в Ярунському районі за 1933 рік не виявлено. - В. $C$.

${ }^{67}$ О. Воловина, С. Плохій, “Регіональні відмінності втрат від голоду 1932 -1934 рр. в Україні”, Український історичний журнал, № 2, (2017): 95.

${ }^{68}$ Державний архів Одеської області (далі “ ДАОО), ф. Р-2009, оп. 1, спр. 4, арк. 64.

${ }^{69}$ ДАХО, ф. Р-3683, оп. 2, спр.2, арк. 52.

${ }^{70}$ Там само, арк. 52.
} 
У квітні 1934 р. сільрадам Вінниччини також надійшла подібна вказівка: "Негайно відберіть книжки ЗАГС про смерть за 1932 та 1933 роки і надішліть такі до спецчастини міськради..."71.

Що це дало яскраво свідчать факти по Красноградському району Харківської области - ця передача призвела до того, що багато документів просто зникла. Про абсолютно незадовільне збереження документів про реєстрацію руху людности під час Голодомору 1932-1933 років можемо переконатися з аналізу матеріялів органів ЗАГСу, які були нещодавно передані до Державного архіву Полтавської области. Наприклад, в Шершнівці Лубенського району свідоцтва про народження за всі передвоєнні роки $\epsilon^{72}$, а документів про смерть за 1932 1933 - жодного. Така ж картина і з матеріялами про рух населення села Яблунівка Лохвицького району. Тут є всі документи про народжених у 1930-х роках, а от документи про смерть залишилися лише з $1936 \mathrm{p.}^{73}$

Про який належний облік руху населення можна говорити, якщо в Бабшинській сільраді Кам'янець-Подільського району нинішньої Хмельницької області реєстрацію смертей у 1933 р. розпочали лише 28 липня. Якщо хтось залишався 3 родичів, то смерть людини фіксувалася зі слів, хоч і заднім числом. Але чи могла пам'ять уцілілих та й реєстратора адекватно сприймати ситуацію, коли окремі смерті датувалися... 31 квітнем 1933 p. $^{74}$

Та московську владу менше за все турбувала втрата власне корінних хліборобів - для цього вона перекине у вимерлі українські села вихідців 3 російської глибинки й Білорусі, на збирання врожаю залучить армію й городян. Тим паче, що заступник наркома робітничо-селянської інстпекції СРСР Верменичев повідомляв 15 січня 1933 р. про досить цікаву тенденцію: “Из колхозов Западной области участились случаи самовольного переселения колхозников на Украину, чем в значительной степени способствуют местные и областные колхозные и зем. организации Украины. Так, коммуна им. Ленина (Шумячского района Запад. обл.), не вошедшая в план переселения, самовольно отправила ходаков в Донецкую область и там заручилась ходатайством Донецкого Обл. ЗУ Буденновской МТС о переселении к ним коммуны.

Ровнянские организации (Одесская обл.) способствуют переселению группы колхозников деревни Воронцы (Смоленский район Запад. обл.). Нововасильевское РайЗО Днепропетровской обл. 22. Х сообщило Зап. ОблЗУ, что колхоз "Краском" Ельнинского района Зап. обл. ими приписан в колхоз "Гигант" их района"75.

Чому на цьому аспекті наголошуємо? Та тому що всі оті переселенці 19321936 років 3-поза меж УСРР разом зі своїми родинами будуть записані в січні

\footnotetext{
${ }^{71}$ Вінниччина, (1993).

72 ДАПО, ф. Р-9126, оп. 8, спр. 45-98.

73 ДАПО, ф. Р-9126, оп. 10, спр. 119.

${ }^{74}$ ДАХмО, ф. Р-6449, оп. 1, спр. 21, арк. 4.

${ }^{75}$ ЦДАВО, ф. 539, оп. 19, спр. 219, арк. 92.
} 
ISSN 2078-6077. Наукові зошити історичного факультету Львівського університету. 2020. Випуск 21. Proceedings of History Faculty of Lviv University. 2020. Issue 21.

1937 р. до населення УСРР, відтак воно і збільшиться до 26. 812 тисяч. Це збільшення буде також і за рахунок тих голодних українських селян, які намагалися через поліські болота, Збруч і Дністер дістатися до Польщі й Румунії, але їх розстріляли радянські прикордонники, абовони не допливли до рятівного берега, де сподівалися дістати так бажаного хліба.

Російські дослідники наводять дані, що за 1932 р. прикордонники ДПУ УСРР розстріляли 5.450 осіб $^{76}$.Скільки цих нещасних поглинули хвилі Дністра чи Збруча - невідомо. Як не знаємо і про тих, хто помер від застудних хвороб. Поки що не встановлено жодних конкретних цифр втрат у 1933 р. Знаємо лише, що тоді при переході кордону з СРСР затримано 1.902 особи $^{77}$.

Згадані переселенці до УСРР у 1937 р. будуть також записані на місці тих, хто лежить у братських могилах біля залізничних станцій, трупи яких скидали в загальні ями без належної реєстрації. Таких поховань в Україні щонайменше 837 - і жодне не досліджене. Знаємо лише, що біля станції Булацелівка на Харківщині, наприклад, від грудня 1932 до травня 1933 виявилося до десяти тисяч трупів ${ }^{78}$.

А хто порахував тих українців, котрі пішли за хлібом до Росії чи Білорусі і там померли? Секретар Кантемирівського райкому ВКП(б) ЦентральноЧорноземної області Журилов писал секретареві обкому Варейкісові ще 1-го квітня 1932 р., що в Кантемирівці “только за последние дни похоронено 12 человек пришедших за хлебом с украинских соседних районов"79.

Мешканка Слободи Мозирського району Білорусі П. Жильська згадувала: “Был сильный голод. К нам шли украинцы. Хотелось им дать. Украинцы приходили и умирали под забором. Падали и умирали"в0.

Подібно свідчить і В. Буйновець 3 цього ж села: "Украинцы приходили, прямо под забором умирали”. Така ж картина закарбувалася і В. Дулуб з села Малі Автюки: “...много украинцев умирало. Просили хлеба, а потом падали и умирали" "81.

Російський дослідник Віктор Кондрашин стверджує, що в 1932 р. “сам факт голода на Украине был шоком для русских крестьян. Показательна в этом плане реакция белорусов. Летом 1932 г. Белоруссия оказалась заполнена голодающими сельскими жителями с Украины. Изумленные белорусские рабочие писали в “Правду” и высшему руководству страны, что они не помнят, чтобы когда бы то ни было "Белоруссия кормила Украину"

${ }^{76}$ И. Чигирин, Миф и правда о сталинском голодоморе, доступ отримано 6 червня 2020 p. http://you-books.com/book/I-Chigirin/Mif-i-pravda-o-Stalinskom-golodomore-Ob-ukrainskoj.

77 ЦДАГО, ф. 1, оп. 20, спр. 6582, арк. 49.

${ }^{78}$ Голодомор 1932-1933 років в Україні, 571.

${ }^{79}$ ЦДАГО, ф. 1, оп. 20, спр. 5255, арк. 16.

${ }^{80}$ И. Романова, “Голод в БССР”, Міжнародна конференція “Штучні голоди в Украйні ХХ століття”. Київ, 16 травня 2018 року. Матеріали. (Київ, 2018): 554.

${ }^{81}$ Там само.

${ }^{82}$ В. Кондрашин, Голод 1932"1933 годов. (Москва, 2008), 180. 
Заангажована на цифру втрат у 3,9 млн осіб, названа українсько-американська група відкидає й інші пропозиції підрахунку, які можуть допомогти встановити реальні втрати. Зокрема, вона не звертає уваги на відповідність прийому до перших класів дітей 8-річного віку, починаючи від 1-го вересня 1933 р., з кількістю народжених свого часу в конкретних населених пунктах. Чому, скажімо, вказаних демографів та істориків не насторожив той факт, що 1 вересня 1932 р. до перших класів Петриківського району Дніпропетровської области влилося 1737 дітей, а через рік до другого класу перейшло лише 911. Така ж тенденція виявилася i щодо другокласників і третьокласників: відповідно 1275 і 749, 1126 і $759^{83}$.

Якщо вона була такою повсюдно, то принаймні мільйон дітей не дорахувалася українська школа 1 вересня 1933 р. лише в цих трьох початкових класах.

Недобір першокласників давав про себе знати і в наступних роках, що бачимо на конкретних фактах. Так, 1 вересня 1935 р., скажімо, в перші класи початкових (п), неповносередніх (нс) і середніх (c) шкіл Плисківського і Погребищенського районів, що входили тоді до Київської области, прийшло набагато менше дітей, ніж їх народилося 1927 p. ${ }^{84}$ Наприклад, за парти Адамівської початкової Плисківського району сіло 34 першаки, а в 1927 у цьому населеному пункті на світ з'явилося 68 дітей, у Андрушівській (нс) ці показники були відповідно 41 і 135, Обозівській (п) - 17 і 57, Паріївській (п) - 18 і 37, Попівській (п) - 14 і $42^{85}$.

Подібна ситуація склалася і в сусідньому, Погребищенському районі. Скажімо, показники Ординецької (нс) - 30 і 76, Борщагівської (нс) - 29 і 93, Круподеринецької (нс) - 63 і 78, Павлівської (нс) - 66 і 100, Білешківської (нс) 37 і 106, Гопчицької (нс) - 78 і 108, Старостинецької (нс) - 36 і 106, Люлинецької (п) - 19 і 42, Кулешівській (п) - 11 і 25, Іваньківській (п) - 19 і $25^{86}$.

Не менш наочною $є$ картина і щодо наповнення початкових класів Баришівського району Київської області станом на 1-го вересня 1940 р. (неповні дані про народження за відповідний рік). 3 цісї таблиці, до речі, можна переконатися, що найбільших втрат зазнала саме вікова група 1932 р., тобто народжені перед Голодомором, а відтак найменш зміцнілі перед таким суворим випробуванням ${ }^{87}$.

${ }^{83}$ ДАДО, ф. П-19, оп. 1, спр. 483, арк. 154.

${ }^{84}$ ДАВО, ф. 6129, оп. 4, спр. 11, 15, 17, 18, 19, 21, 22, 23, 24, 25, 26,30, 31, 32,33, 34, 38, $39,40,41,42,43,47,48,49,50,51,56,57,58,59,60,61,62,63,64,65$.

${ }^{85}$ ДАКО, ф. Р-144, оп. 1, спр. 1866, арк. 1-65.

86 ДАКО, ф. Р-144, оп. 1, спр. 1882, арк. 1-48.

87 ДАКО, ф. Р-144, оп. 1, спр. 2538, арк. 1-26. 
ISSN 2078-6077. Наукові зошити історичного факультету Львівського університету. 2020. Випуск 21. Proceedings of History Faculty of Lviv University. 2020. Issue 21.

\begin{tabular}{|c|c|c|c|c|c|}
\hline $\begin{array}{l}\text { Населенні } \\
\text { пункти }\end{array}$ & $\begin{array}{l}\text { Народилося } \\
\text { в } 1932 \text { році }\end{array}$ & $\begin{array}{c}3 \\
\text { народжених } \\
\text { у } 1932 \text { році } \\
\text { пішло до } 1 \\
\text { класу в } \\
1940 \text { році }\end{array}$ & $\begin{array}{c}3 \\
\text { народжених } \\
\text { у } 1931 \text { році } \\
\text { пішло до } 2 \\
\text { класу в } \\
1940 \text { році }\end{array}$ & $\begin{array}{c}3 \\
\text { народжених } \\
\text { у } 1930 \text { році } \\
\text { пішло до } 3 \\
\text { клас у в } \\
1940 \text { році }\end{array}$ & $\begin{array}{c}3 \\
\text { народжених } \\
\text { у } 1929 \text { році } \\
\text { пішло до } 4 \\
\text { класу в } \\
1940 \text { році }\end{array}$ \\
\hline Баришівка & 46 & 23 & $46 / 35$ & $75 / 34$ & $85 * / 35$ \\
\hline Бзів & $40 *$ & 13 & $52 / 24$ & $76 / 29$ & $60 / 36$ \\
\hline Борщів & 16 & 4 & $24 / 3$ & $33 / 14$ & $28 / 15$ \\
\hline Війтовці & 108 & 10 & $151 / 56$ & $148 / 59$ & $60 * / 78$ \\
\hline Власівка & $27 *$ & 8 & $32 / 19$ & $39 / 33$ & $46 / 44$ \\
\hline Волошинів ка & $24 *$ & 13 & $41 / 20$ & $39 / 38$ & $46 / 20$ \\
\hline Гостролуччя & 76 & 51 & $107 / 77$ & $121 / 73$ & $114 / 64$ \\
\hline Дернівка & 38 & 13 & $28 / 23$ & $34 / 26$ & $42 / 34$ \\
\hline Коржі & $20 *$ & 5 & $12 / 12$ & $23 / 20$ & $27 / 20$ \\
\hline Корніївка & 40 & 7 & $53 / 29$ & $64 / 52$ & $66 / 35$ \\
\hline Липняки & 39 & 19 & $-/ 23$ & $38 / 32$ & $40 / 27$ \\
\hline Лукаші & $26 *$ & 27 & $64 / 38$ & $84 / 40$ & $68 / 38$ \\
\hline Лук'янівка & 41 & 10 & $50 / 17$ & $55 / 32$ & $61 / 31$ \\
\hline $\begin{array}{l}\text { Мала } \\
\text { Стариця } \\
\end{array}$ & 17 & 7 & $23 / 20$ & $27 / 19$ & $26 / 11$ \\
\hline Морозівка & 44 & 17 & $49 / 34$ & $75 / 44$ & $77 / 35$ \\
\hline Масківці & 47 & 6 & $47 / 26$ & $69 / 28$ & $64 / 12$ \\
\hline Паришків & 51 & 16 & $63 / 35$ & $61 / 29$ & $73 / 49$ \\
\hline Пасічна & 20 & 12 & $16 / 15$ & $-/ 18$ & $-/ 33$ \\
\hline Рудницьке & 35 & 16 & $39 / 15$ & $43 / 17$ & $63 / 35$ \\
\hline С еличівка & 58 & 17 & $63 / 35$ & $68 / 36$ & $65 / 39$ \\
\hline Селище & $2 *$ & 15 & $61 / 40$ & $58 / 35$ & $54 / 29$ \\
\hline Сизенків & 21 & 12 & $18 / 17$ & $32 / 29$ & $23 / 14$ \\
\hline Скопці & 96* & 29 & $118 * / 72$ & $205 / 93$ & $187 / 80$ \\
\hline
\end{tabular}

І навіть у такому поліському районі Київщини, як Іванківський, де, здавалося, багатства лісів і річок мали б зарадити масовому Голодоморові, школи прийняли в 1940 р. також набагато менше першокласників. А в багатьох селах тут узагалі не набрали перших класів, хоч 8 років перед тим там народилося достатня кількість дітей для їх відкриття. Як і перед тим, що давало можливість мати перші класи в 1937-1939 роках $^{88}$.

${ }^{88}$ ДАКО, ф. Р-5634, оп. 1, спр. 421, 422; ф. Р-144, оп. 1, спр. 2541, арк.1-41. 
ISSN 2078-6077. Наукові зошити історичного факультету Львівського університету. 2020. Випуск 21. Proceedings of History Faculty of Lviv University. 2020. Issue 21.

\begin{tabular}{|c|c|c|c|c|c|c|c|}
\hline Школи & $\begin{array}{l}\text { Наро } \\
\text { дилос } \\
\text { я в } \\
1932 \\
\text { році } \\
\end{array}$ & $\begin{array}{l}\text { Пішло } \\
\text { до } 1 \\
\text { кл асу } \\
\text { в } 1940 \\
\text { році }\end{array}$ & $\begin{array}{l}\text { У тому } \\
\text { числі } \\
\text { 8- } \\
\text { річних }\end{array}$ & $\begin{array}{l}\text { Пішло } \\
\text { до } 2 \\
\text { класу } \\
\text { в } 1940 \\
\text { р оці } \\
\end{array}$ & $\begin{array}{l}\text { Пішло } \\
\text { до } 3 \\
\text { класу } \\
\text { в } 1940 \\
\text { році } \\
\end{array}$ & $\begin{array}{l}\text { Пішло } \\
\text { до } 4 \\
\text { класу } \\
\text { в } 1940 \\
\text { році } \\
\end{array}$ & Разом \\
\hline Білоберезька п & $19 *$ & - & - & 15 & 21 & 17 & 53 \\
\hline Блідчанська нс & $23 * T p$ & 24 & 15 & 58 & 45 & 53 & 180 \\
\hline Болотнянська п & 14 & - & - & 16 & 10 & 12 & 32 \\
\hline Воропаївська п & 13 & - & - & 15 & 30 & - & 45 \\
\hline $\begin{array}{l}\text { Ворошилів- } \\
\text { ська п }\end{array}$ & - & 20 & 14 & 19 & 25 & 16 & 77 \\
\hline Доманівська нс & - & 11 & 1 & 17 & 23 & 19 & 70 \\
\hline Запрудська нс & 40 & 34 & 48 & 29 & 44 & 38 & 155 \\
\hline Зимовицька п & 8 & 11 & 8 & 8 & - & 9 & 28 \\
\hline Іванківська с & 60 & 46 & 35 & 60 & 55 & 73 & 234 \\
\hline Карпилівська п & 17 & - & - & 16 & 16 & 6 & 38 \\
\hline Ковалі вська п & 14 & - & - & 17 & 25 & - & 42 \\
\hline Коленцівська нс & 50 & 30 & 13 & 50 & 28 & 26 & 134 \\
\hline $\begin{array}{l}\text { Красилівська } \\
\text { рнс }\end{array}$ & 62 & 19 & 11 & 25 & 33 & 29 & 106 \\
\hline Леонівськанс & $17 *$ & 22 & 8 & 16 & 25 & 12 & 75 \\
\hline Любидванська п & 6 & - & - & 12 & - & 20 & 32 \\
\hline Макарі вська нс & 36 & 31 & 17 & 34 & 57 & 55 & 177 \\
\hline $\begin{array}{l}\text { Новомакале- } \\
\text { вицька п }\end{array}$ & 25 & 10 & 4 & 21 & 14 & 17 & 62 \\
\hline $\begin{array}{l}\text { Новосокільська } \\
\text { нс }\end{array}$ & 37 & 10 & 2 & 10 & 20 & 18 & 58 \\
\hline Обуховицька с & 67 & 40 & 15 & 79 & 74 & 62 & 255 \\
\hline Ораненська нс & 22 & 21 & 9 & 25 & 27 & 38 & 111 \\
\hline $\begin{array}{l}\text { Орджонікідзев- } \\
\text { ська п }\end{array}$ & 9 & 9 & 1 & 9 & 16 & 14 & 48 \\
\hline Оцительська нс & 33 & 10 & 3 & 30 & 35 & 35 & 110 \\
\hline $\begin{array}{l}\text { Пироговицька } \\
\text { нс }\end{array}$ & 27 & 5 & 3 & 18 & 24 & 28 & 75 \\
\hline Потоцька п & 17 & 9 & 3 & 12 & 15 & 15 & 51 \\
\hline Приборська нс & 43 & 27 & 20 & 37 & 57 & 55 & 176 \\
\hline $\begin{array}{l}\text { Руднетальська } \\
\text { нс }\end{array}$ & 26 & 9 & 4 & 17 & 34 & 17 & 77 \\
\hline Русаківська нс & 38 & 16 & 5 & 29 & 37 & 39 & 121 \\
\hline $\begin{array}{l}\text { Русаківська } \\
\text { (дитбудинок) }\end{array}$ & - & 34 & 21 & 29 & 35 & 31 & 123 \\
\hline Станиші вська нс & $16^{*}$ & 24 & 10 & 60 & 39 & 58 & 181 \\
\hline $\begin{array}{l}\text { Старосоколів- } \\
\text { ська п }\end{array}$ & 17 & 9 & 5 & 14 & 15 & 20 & 58 \\
\hline Сукачівська нс & 54 & 56 & 30 & 34 & 35 & 40 & 145 \\
\hline Федорів ська п & - & - & - & 12 & 13 & 15 & 40 \\
\hline
\end{tabular}


ISSN 2078-6077. Наукові зошити історичного факультету Львівського університету. 2020. Випуск 21. Proceedings of History Faculty of Lviv University. 2020. Issue 21.

\begin{tabular}{|l|l|l|l|l|l|l|l|}
\hline Феневицька с & 78 & 40 & 20 & 43 & 70 & 60 & 213 \\
\hline Хочівська п & - & - & - & 11 & 17 & - & 28 \\
\hline Шпилівська нс & 48 & 26 & 15 & 33 & 49 & 20 & 128 \\
\hline
\end{tabular}

А як вижили народжені в 1932 р. і в колишньому Іркліївському районі Полтавської області, який входить тепер до складу Чорнобаївського на Черкащині, можна бачити з наступної таблиці, хоч у документах відсутні дані про вік першокласників. Але знову ж таки найбільших втрат зазнали найменші, якщо врахувати, що народжуваність в українському селі на помежів'ї 1920-х років була приблизно однаковою ${ }^{89}$.

\begin{tabular}{|c|c|c|c|c|c|}
\hline Школи & $\begin{array}{l}\text { Народилося } \\
\text { в } 1932 \text { році }\end{array}$ & \begin{tabular}{ll}
\multicolumn{2}{l}{ Пішло } \\
до & 1 \\
класу & в \\
1940 & \\
році &
\end{tabular} & $\begin{array}{ll}\text { Пішло } & \\
\text { до } & 2 \\
\text { класу } & \text { в } \\
1940 \text { році }\end{array}$ & \begin{tabular}{ll}
\multicolumn{2}{l}{ Пішло } \\
до & 3 \\
класу & в \\
1940 & \\
році &
\end{tabular} & $\begin{array}{ll}\text { Пішло } \\
\text { до } & 4 \\
\text { класу } & \text { в } \\
1940 & \\
\text { році } & \end{array}$ \\
\hline Іркліївсь ка с & 29 & 14 & 18 & 35 & 17 \\
\hline Лихолітська нс & 35 & 21 & 42 & 56 & 43 \\
\hline Павленківська п & 8 & - & 18 & - & 22 \\
\hline Лящівська нс & 70 & 40 & 56 & 81 & 68 \\
\hline Михайлівська п & 4 & - & 37 & - & 28 \\
\hline Загородищенська п & 11 & - & 40 & - & 35 \\
\hline Черв оногорська п & 22 & 7 & - & 17 & - \\
\hline Каврайська п & 12 & 5 & - & 19 & - \\
\hline Демківська п & 24 & 15 & 20 & 26 & 29 \\
\hline Бузьківська п & 30 & 6 & 24 & 35 & - \\
\hline Нам існянська п & - & 5 & 7 & 13 & - \\
\hline Кітлівська п & $6 *$ & 8 & 23 & 31 & - \\
\hline Васютинська п & 89 & 25 & 35 & 31 & 37 \\
\hline Васютинська с & - & 28 & 44 & 44 & 40 \\
\hline Старосільська п & 14 & - & 22 & 33 & - \\
\hline Чехівська п & 15 & - & 26 & - & 31 \\
\hline Червонохижинська п & 23 & - & 23 & 31 & - \\
\hline Мутиська п & 27 & 13 & - & 25 & - \\
\hline Мойсінська нс & 31 & 18 & 27 & 38 & 41 \\
\hline Пищиківська нс & 14 & 7 & 5 & 22 & 21 \\
\hline Москаленська нс & 69 & 48 & 43 & 55 & 40 \\
\hline Ревбінська нс & 36 & 16 & 37 & 41 & 45 \\
\hline Староковрайська нс & 37 & 17 & 25 & 27 & 33 \\
\hline Першомайська нс & 24 & 10 & 21 & 22 & 27 \\
\hline Скородиська нс & 49 & 31 & 57 & 41 & 46 \\
\hline Черв оносільська нс & 32 & 9 & 10 & 32 & 32 \\
\hline
\end{tabular}

${ }^{89}$ ДАЧО, ф. Р-5899, оп. 23, спр. 1, 2, 5, 7, 8, 9, 10, 11, 12, 13, 14, 15, 16, 17, 18, 19, 20, 21, 22, $23,24,25,25,26,51,52,59,60,63,67 . ;$ ДАПО, ф. 3938, оп. 1, спр. 195, арк. 69-72. 
ISSN 2078-6077. Наукові зошити історичного факультету Львівського університету. 2020. Випуск 21. Proceedings of History Faculty of Lviv University. 2020. Issue 21.

\begin{tabular}{|l|l|l|l|l|l|}
\hline Воронинська нс & 27 & 13 & 29 & 32 & 26 \\
\hline Крутьківська нс & 42 & 25 & 56 & 48 & 50 \\
\hline Самовицька нс & 38 & 28 & 22 & 59 & 32 \\
\hline Митьківська нс & 48 & 25 & 38 & 37 & 35 \\
\hline Мельниківська с & 59 & 35 & 42 & 59 & 71 \\
\hline
\end{tabular}

Отже, картина 3 наповненням перших класів сільських загальноосвітніх шкіл України після 1933 р. складається майже скрізь однаковою - 30-40 відсотків дітей, народжених у 1924-1932 роках в УСРР, не сіли за парти. Якщо врахувати, що за 1924-1932 роки на світ появилося близько 10 мільйонів осіб ${ }^{90}$ (скажімо, 1924-1.162,9, 1925 - 1.196,8, 1926 - 1.207,9, 1927 - 1.184,4 тисячі, 1928 - 1.139,3, 1929 - 1.080,0, 1930 - 1.023,0, 1931-975,3, 1932-782,0 - цей приріст відбувався головно за рахунок села), то цілком вірогідним є втрата у 1932-1933 роках щонайменше 3-х мільйонів першокласників і майбутніх школярів початкових класів. А якщо додати до цих жертв Голодомору і тих, хто в 1933 належав до середнього і старшого шкільного віку, то матимемо ще мінімум півмільйона жертв.

Виходячи з того, що втрати тільки дітей дошкільного і шкільного віку становили щонайменше 3,5 мільйона осіб, вважаємо цілком реальним, що мінімум 7 мільйонів населення УСРР стали жертвами Голодомору-геноциду 1932-1933 років.

Докторка економічних наук Н. Левчук дорікає мені на сторінках "УІЖ” за те, що я пропоную “розрити кожну безіменну могилу на території країни”, що видається їй неможливим. Так, дослідити кожне з відомих на сьогодні 837 поховань - це величезна праця. Як і встановлення кількости похованих голодних українців у Росії й Білорусі, розстріляних на кордоні чи потопельців у Дністрі й Збручі, жертв канібалів, а то й зовсім не похованих, кістки яких розтягнули здичавілі собаки. Але без цих даних ми не можемо встановити реальну кількість втрат від Голодомору 1932-1933 років. І ніякі кабінетні формули наших демографів тут не допоможуть - лише сумлінне вивчення первинних документів українських архівів, що має стати обов'язком кожного, хто досліджує Голодомор-геноцид 1932-1933 років в Україні.

${ }^{90}$ Природний рух людности Украӥни в 1929 р. (Харків: Господарство України, 1932), 13; ЦДАГО, ф. 1, оп. 20, спр. 7163, арк. 16. 
ISSN 2078-6077. Наукові зошити історичного факультету Львівського університету. 2020. Випуск 21. Proceedings of History Faculty of Lviv University. 2020. Issue 21.

\title{
PRIMARY DOCUMENTS OF THE UKRAINIAN ARCHIVES AS THE MAIN SOURCE FOR DETERMINING THE LOSSES DURING THE HOLODOMOR-GENOCIDE 1932-1933
}

\author{
Volodymyr SERHIICHUK \\ Taras Shevchenko National University of Kyiv \\ Head of the Department of History of World Ukrainians \\ Volodymyrska str. 60 Kyiv, 01033, Ukraine \\ e-mailserhijchuk@ukr.net
}

The research goal is to evaluate the achievements of Ukrainian and foreign historical and demographic science on the counting of victims of the 1932-1933 Holodomor-Genocide in Ukraine and to propose new approaches to achieving a real result. The research methodology is based on common scientific methods of analysis, comparison and generalization. Also comparative-historical, structural and systemfunctional methods were applied. Scientific novelty. For the first time, the victims of the 1932"1933 Famine Genocide were estimated on the basis of official Soviet statistics on the number of the Ukrainian SSR population as of January 1, 1932, and its estimated number as of January 1, 1934. In addition, a comparative analysis of the number of births in the Ukrainian SSR in 1924"1932 with the filling of the first classes in 1932"1940 by children of 8 years of age (it was when they first came to school), using the coefficient of natural loss in those ages groups. Conclusions. Given the lack of archival documents on the specific losses from the 1932"1933 Holodomor-Genocide in Ukraine, only a careful analysis of the existing primary documents makes it possible to identify the closest possible number of victims of this tragedy to our people. Thanks to this, it was possible to establish the official figure of the population of the USSR as of January 1,1932 and to calculate it on January 1, 1934, which gives grounds to claim the minimal losses during the Holodomor-Genocide of 7 million people. This figure is confirmed by the analysis of the first classes filling of 8 -year-old children, who at that age first came to school, in many districts of Kyiv region, Cherkasy region, Vinnytsia region, Poltava region. For example, in the Tarashchansky district of Kyiv region, 2,701 children were born in 1928, and in 1936 only 1060 of them went to desks in the first classes. In the villages of the left-bank Pereyaslavsky district is a similar situation: from 3487 babies from 1931 to 1939 only 1591 survived. Allowing natural losses in the normal situation, even up to 20 percent, in both cases, child mortality due to the Holodomor had catastrophic consequences: approximately 40 percent of those born in the respective years. The same tragic results are obtained by analyzing the primary documents of the Orativsky, Plyskivsky and Pogrebyshchensky districts of Vinnitsa region, in the absolute majority of schools in Poltava region. Considering that about 10 million children were born in the Ukrainian SSR between 1924 and 1932, their deaths during the HoljdomorGenocide were at least 3 million, and from the number of schoolchildren born before 1924, about 500,000 more died then. That is, the infant mortality of school age reached at least 3.5 million people in 1932"1933, and the total, as German diplomats testified then, from 7 to 10 million. The final result can be established after counting the deaths of those who left the Ukrainian villages in search of bread and died in Russia or Belarus, or on the way to these regions - we have not yet investigated any of the 837 mass graves near railway stations or river piers, none counted those who fell into Zbruch or Dnister, fleeing famine to Poland or Romania, or who were shot by Soviet border guards. Also, it is not yet counted how much labor was imported from 1932 to 1936 from other republics, which was already recorded by residents of the Ukrainian SSR during the All-Union Census of 1937.

Keywords: Holodomor-Genocide of 1932-1933, calculation of losses on the basis of primary documents, filling. 


\section{References \\ Arkhivni materialy Karkivski Kharkivskoi oblasnoi orhanizatsii "İemorial" z Holodomoru. Tablytsia 13.}

Bohorad, D. Raionnaia planirovka Donetskoho, (Kyiv: Hostekhizdat, 1947).

Chigirin, I. Mif i pravda o stalinskom golodomore otrymano dustup $06.06 .2020 \mathrm{http}: / /$ youbooks.com/book/I-Chigirin/Mif-i-pravda-o-Stalinskom-golodomore-Ob-ukrainskoj.

Derzhavnyi arkhiv Vinnytskoyi oblasti, f. Đ-2071, op. 1, spr. 348, ark. 50.

Derzhavnyi arkhiv Vinnytskoyi oblasti, f. Đ-2071, op. 1, spr. 355, ark. 78.

Derzhavnyi arkhiv Vinnytskoyi oblasti, f. 6129, op. 4, spr. 11, 15, 17, 18, 19, 21, 22, 23, 24, 25, $26,30,31,32,33,34,38,39,40,41,42,43,47,48,49,50,51,56,57,58,59,60,61,62,63,64,65$.

Derzhavnyi arkhiv Dnipropetrovskoyi oblasti, f. П-19, op.1, spr. 525, ark. 49 zv.

Derzhavnyi arkhiv Dnipropetrovskoyi oblasti, F. П-19, op.1, spr. 529, ark. 123 zv.

Derzhavnyi arkhiv Dnipropetrovskoyi oblasti, f. П-19, op. 1, spr. 483, ark. 154.

Derzhavnyi arkhiv Zaporiz'koi oblasti, f. 5593, op. 13, spr. 276, 313-317, 321.

Derzhavnyi arkhiv Zaporiz'koi oblasti, f. Đ-5593, op. 16, spr. 110, ark. 39-42, 49, 51, 61-65, 67, 77-79, 86-87, 91.

Derzhavnyi arkhiv Zaporiz'koi oblasti, f. Đ-5593, op. 20, spr. 148, ark. 100-102, 105-106, 108, 111-112, 114-119, 122, 125.

Derzhavnyi arkhiv Zaporiz'koi oblasti, f. Đ-5593, op. 20, spr. 149, ark. 181-191, 193, 196-198, 200.

Derzhavnyi arkhiv Zaporiz'koi oblasti, f. Đ-5593, op. 21, spr. 207, ark. 152-153.

Derzhavnyi arkhiv Kyivskoi oblasti, f. P-144, op. 1, spr. 58, ark. 155-156.

Derzhavnyi arkhiv Kyivskoi oblasti, f. Đ-144, op. 1, spr. 1866, ark. 1-65.

Derzhavnyi arkhiv Kyivskoi oblasti, f. Đ-144, op. 1, spr. 1882, ark. 1-48.

Derzhavnyi arkhiv Kyivskoi oblasti, f. Đ-144, op. 1, spr. 2538, ark. 1-26.

Derzhavnyi arkhiv Kyivskoi oblasti, f. Đ-144,op. 1, spr. 2541, ark.1-41.

Derzhavnyi arkhiv Kyivskoi oblasti, f. Đ-5634, op. 1, spr. 421, 422.

Derzhavnyi arkhiv Poltavskoi oblasti, f. 3938, op. 1, spr. 195, ark. 69-72.

Derzhavnyi arkhiv Poltavskoi oblasti, f. Đ-9126, op. 8, spr. 45-98.

Derzhavnyi arkhiv Poltavskoi oblasti, f. Đ-9126, op. 10, spr. 119.

Derzhavnyi arkhiv Mykolaivskoi oblasti, f. Đ-5950, op. 18, spr. 156, ark. 1-453.

Derzhavnyi arkhiv Odeskoyi oblasti, f. Đ-2009, op. 1, spr. 4, ark. 64.

Derzhavnyi arkhiv Kharkivskoi oblasti, f. Đ-5231, op. 2, spr. 2, ark. 5-5 zv.; spr. 10, ark. 1-1 zv.; spr. 18 , ark. $7-7 \mathrm{zv}$; spr. 27, ark. $7-7 \mathrm{zv}$.

Derzhavnyi arkhiv Kharkivskoi oblasti, f. Đ-3683, op 2, spr. 2, ark. 52.

Derzhavnyi arkhiv Kharkivskoi oblasti, f. Đ-6531, op. 101, spr. 4, ark. 24-26.

Derzhavnyi arkhiv Kharkivskoi oblasti, f. Đ-6531, op. 106, spr. 7, ark. 74.

Derzhavnyi arkhiv Khersonskoi oblasti, f. Đ-4069, op. 7, spr. 142.

Derzhavnyi arkhiv Khmelnytskoi oblasti, f. Đ-6449, op. 1, spr. 21, ark. 4.

Derzhavnyi arkhiv Khmelnytskoi oblasti, f. 6452, op. 1, spr. 210, ark. 151.

Derzhavnyi arkhiv Cherkaskoi oblasti, f. Đ-5899, op. 20, spr. 72, ark. 1-25.

Derzhavnyi arkhiv Cherkaskoi oblasti, f. Đ-5899, op. 23, spr. 1, 2, 5, 7, 8, 9, 10, 11, 12, 13, 14, 15, $16,17,18,19,20,21,22,23,24,25,25,26,51,52,59,60,63,67$.

Derzhavnyi arkhiv Cherkaskoi oblasti, f. Đ-5899, op. 24, spr. 73, ark. 1-30.

Derzhavnyi arkhiv Cherkaskoi oblasti, f. Đ-5899, op. 24, spr. 185, ark. 138-140, 151-153, 155, $176,180,181,192$. 
ISSN 2078-6077. Наукові зошити історичного факультету Львівського університету. 2020. Випуск 21. Proceedings of History Faculty of Lviv University. 2020. Issue 21.

Dovidnyk z osnovnykh statystychno-ekonomichnykh pokaznykiv hospodarstva rayoniv Kyivskoi oblasty USRR. (Kharkiv: Vydannia Upravlinnia spravamy Rady narodnykh komisariv USRR, 1933), 6.

Holodomor 1932-1933: zaporiz'kyi vymir. (Zaporizhzhia: Prosvita, 2008).

Holodomor 1932-1933 rokiv. (Zhytomyr: Volyn, 2008).

Êondrashyn, V. Holod 1932"1933 hodov. (İoskva, 2008).

17. Kropachov, S. "Mashtaby demohraficheskikh poter' SSSR, Nachalo 1930-kh - seredina 1940-kh hodov", Problemy otechestvennoy istorii, (Krasnodar: Ekoinvest, 2010).

Levchuk, N., Boriak, T., Volovyna, O., Rudnytskyi, O., Kovbasiuk, À. "Vtraty miskoho I silskoho naselennia Ukrainy vnaslidok Holodomoru v 1932-1934 rr.", Ukrayinskyy istorychnyyi zhurnal No. 4, (2015).

Levchuk, N. "Do pytannia pro "stari” ta "novi” pidkhody do otsinky vtrat naselenn Ukrainy vnaslidok Holodomoru 1932 - 1933 rr.", Ukrayinskyyi istorychnyyi zhurnal, No. 2, (2018).

Romanova, I. "Holod v BSSR", Mizhnarodna konferentsiia "Shtuchni holody v Ukraini XX stolittia”. Kyiv, 16 travnia 2018 roku. Materialy. (Êyiv, 2018).

Pravda, (1939).

Pryrodnyi rukh ludnosty Ukrainy v 1929 r. (Kharkiv: Hospodarstvo Ukrainy, 1932).

Stalin i Kahanovych. Perepiska. 1931-1936. (İoskva, 2001).

Tsentralnyi derzhavnyi arkhiv vyshykh orhaniv vlady ta upravlinnia Ukrainy, f. 2, op. 12, spr. 1, ark. 143-147.

Tsentralnyi derzhavnyi arkhiv vyshykh orhaniv vlady ta upravlinnia Ukrainy, f. 2, op. 12, spr. 70, ark. 5, 7.

Tsentralnyi derzhavnyi arkhiv vyshykh orhaniv vlady ta upravlinnia Ukrainy, f. 539, op. 10, spr. 80, ark. 185

Tsentralnyi derzhavnyi arkhiv vyshykh orhaniv vlady ta upravlinnia Ukrainy, f. 539, op. 19, spr. 219, ark. 92.

Tsentralnyi derzhavnyi arkhiv hromadskykh obiednan' Ukrainy, f. 1, op. 6, spr. 323, ark. 269.

Tsentralnyi derzhavnyi arkhiv hromadskykh obiednan' Ukrainy, f. 1, op. 16, spr. 19, ark. 72-72 zv.

Tsentralnyi derzhavnyi arkhiv hromadskykh obiednan' Ukrainy, f. 1, op. 20, spr. 5255, ark. 16.

Tsentralnyi derzhavnyi arkhiv hromadskykh obiednan' Ukrainy, f. 1, op. 20, spr. 5313, ark. 84.

Tsentralnyi derzhavnyi arkhiv hromadskykh obiednan'Ukrainy, f. 1, op. 20, spr. 5315, ark. 91.

Tsentralnyi derzhavnyi arkhiv hromadskykh obiednan'Ukrainy, f. 1, op. 20, spr. 5326, ark. 8-9.

Tsentralnyi derzhavnyi arkhiv hromadskykh obiednan' Ukrainy, f. 1, op. 20, spr. 5588, ark. 5.

Tsentralnyi derzhavnyi arkhiv hromadskykh obiednan' Ukrainy, f. 1, op. 20, spr. 5599, ark. 5.

Tsentralnyi derzhavnyi arkhiv hromadskykh obiednan' Ukrainy, f. 1, op. 20, spr. 6237, ark. 33.

Tsentralnyi derzhavnyi arkhiv hromadskykh obiednan' Ukrainy, f. 1, op. 20, spr. 6241, ark. 33.

Tsentralnyi derzhavnyi arkhiv hromadskykh obiednan' Ukrainy, f. 1, op. 20, spr. 6243, ark. 71.

Tsentralnyi derzhavnyi arkhiv hromadskykh obiednan' Ukrainy, f. 1, op. 20, spr. 6276, ark. 2.

Tsentralnyi derzhavnyi arkhiv hromadskykh obiednan' Ukrainy, f. 1,op. 20, spr. 6582, ark. 49.

Tsentralnyi derzhavnyi arkhiv hromadskykh obiednan'Ukrainy, f. 1, op. 20, spr. 7163, ark. 24-46.

Tsentralnyi derzhavnyi arkhiv hromadskykh obiednan'Ukrainy, f. 539, op. 10, spr. 73, ark. 24.

Ukrainski visti, Ch. 11, (Novyi Ulm, 1950).

Vinnychchyna, (1993).

Volovyna O., Plokhiy S., Levchuk N., Rudnytskyi O., Kovbasiuk À., Shevchuk P. "Rehionalni vidminnosti vtrat vid holodu 1932-1934 rr. v Ukraini”, Ukrayinskyyi istorychnyy zhurnal, No. 2, (2017): 76-116.

Vsesoiuznaia perepis naselenia 1937 hoda. Kratkie itohi. (Ìoskva: Institut istorii SSSR, 1991). 